\title{
An exploratory scenario analysis of strategic pathways towards a sustainable electricity system of the drought-stricken São Francisco River Basin
}

\author{
Clécio Barbosa Souza Júnior ${ }^{1}$. Hagen Koch ${ }^{2}$. \\ Marianna Siegmund-Schultze ${ }^{1}$. Johann Köppel ${ }^{1}$
}

Received: 7 May 2018 / Accepted: 12 May 2019 / Published online: 10 June 2019

(c) The Author(s) 2019

\begin{abstract}
The São Francisco River Basin in Brazil's Northeast region suffered from a serious multi-year drought, which started in 2012. This drought was characterized by long periods of water stress, variability and unpredictability of levels and flows of rivers and reservoirs, decreases in hydropower generation, and rising of conflicts between agricultural and electrical sectors. Besides, the electricity sector faced a crisis due to its dependency on hydroelectricity generation. Applying a Multi-Criteria Decision Analysis (MCDA) can contribute to resolve such conflicts. Particular challenges are establishing transparent rules for water level management at the dams and securing electricity supply. Ultimately, identifying options to invest in sustainable power sources may positively impact the regional electricity matrix. We used Soft Systems Methodology to structure the decision-making context and set the main objectives to be considered in the MCDA. Different scenarios of reservoir management were simulated using the Soil and Water Integrated Model and Incomplete Pairwise Comparison, while bibliographic research and expert interviews led to the selection of indicators for structuring the MCDA. We present projections for hydropower generation and meeting of water demands of further users, based on two climate change projections. The driest scenario shows a reduction in hydropower generation, indicating the necessity to reconfigure the composition of electricity sources, considering economic, technical and social-environmental constraints. These elements of the structuring phase are prerequisites for the evaluation phase of the MCDA.
\end{abstract}

Keywords Multi-criteria decision analysis · Problem structuring · Scenarios · Hydropower generation · Water availability · Sustainability

Clécio Barbosa Souza Júnior junior@campus.tu-berlin.de

Extended author information available on the last page of the article 


\section{Introduction}

The electricity sector performs an important role in the economic and social development of a country [70]. It has the task of interacting with the environment and sustainably using natural resources while making economic profits and absorbing social consequences [48]. A simplistic model with a traditional approach and a single criterion cannot capture the complexities of current energy systems [21]. The trend of new governmental policies has been to introduce measures for energy efficiency and implement tools to provide support for water governance and the use of renewable and sustainable energy [1, 12, 13, 58]. Thus, the adoption of multi-criteria models has been widely used in matters which involve electricity planning [14]. Amer and Daim [5], for example, compared four types of technologies for renewable electricity generation in Pakistan and results showed that wind power and biomass were the most favorable. Garni et al. [25] and Kahraman et al. [33] studied Saudi Arabia and Turkey, respectively, and highlighted the importance of solar and wind power in the strategic planning of those countries. Luthra et al. [41] and Wijayatunga et al. [78] used a multicriteria model to identify the main barriers in adopting renewable energies in India and Sri Lanka, respectively. Cannemi et al. [15], Kambezidis et al. [34], Karatayev et al. [35] and Shen et al. [71] used Multi-Criteria Decision Analysis (MCDA) to elaborate policies for the development of sustainable energies in Italy, Greece, Kazakhstan and Taiwan, respectively. Moreover, Koch et al. [37] highlighted expected benefits of hydro- and wind power integrated energy systems in Brazil.

In Brazil's Northeast (NE) hydropower generation is highly dependent on the São Francisco River Basin, since $41 \%$ of the installed capacity is hydropower and $86 \%$ of this installed capacity comes from the plants of Sobradinho, Itaparica, Complexo Paulo Afonso and Xingó [51], located in the São Francisco River (Fig. 1). The NE has around 28,950 MW of installed capacity distributed amongst hydropower, thermoelectric (biomass and fossil fuels), wind and solar energies (see Table 1).

In this context, the reservoirs are of major importance for electricity generation and exert high pressures on other sectors that use water. Meteorological and following hydrological droughts compel the reduction of flows into and downstream of reservoirs causing, among other consequences, non-compliance of environmental flows and negative impacts on life and work conditions of communities near the reservoirs. The Três Marias, Sobradinho and Xingó Reservoirs have been enduring flow reductions since 2013. Três Marias' official minimal flow was reduced from 500 to $150 \mathrm{~m}^{3} / \mathrm{s}$ [7], and the Sobradinho and Xingó Reservoirs had their discharge gradually reduced during the 5 years before 2018 (period in which this paper has been written) from 1300 to $600 \mathrm{~m}^{3} / \mathrm{s}$ [8]. Since 2012 electricity generation from hydraulic sources has declined (Fig. 2), as has also been observed by Koch et al. [37], due to the hydrological drought in the region. To compensate for the loss in hydropower generation there has been a rise in thermal electricity generation. Besides, since 2013 wind power generation has also been growing. According to the Brazilian Energy Decennial Plan 2024 [45] the $\mathrm{NE}$ is the region with the largest potential for wind power generation.

Reservoir management is one of the main points discussed in the negotiation process for water allocation among the different users of the São Francisco River Basin. 


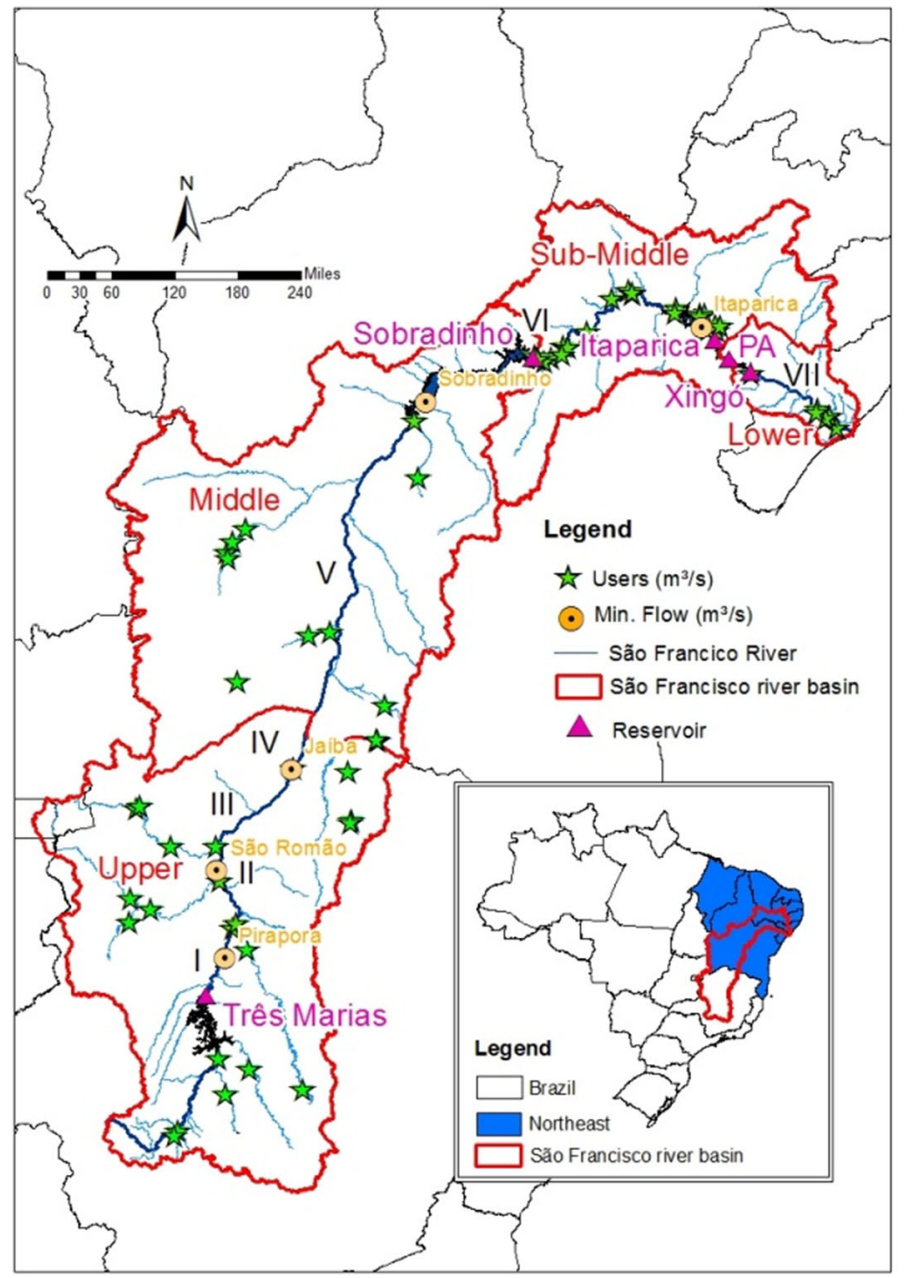

Fig. 1 São Francisco River Basin, main reservoirs, users (large individual irrigation and aggregation of smaller users) — and points of minimal flows used in the scenarios' simulations

The conflicts caused by the reduction of discharges authorized by IBAMA, ${ }^{1} \mathrm{ANA}^{2}$ and $\mathrm{ONS}^{3}$ for the electricity sector are more latent in the Sub-Middle and Lower São Francisco [57]. Furthermore, $\mathrm{CBHSF}^{4}$ [17] highlights that the unpredictability of reservoir discharges and vague communication destabilize fishing, navigation, tourism, fish farming activities and life conditions of riverside communities. To resolve these conflicts Silva [68], Garjulli [24], Ramina [57] and CBHSF [17] are unanimous in underlining the necessity of reducing the dependency on the river basin for hydropower

\footnotetext{
${ }^{1}$ IBAMA—Brazilian Institute of Environment and Renewable Natural Resources.

2 ANA-National Water Agency.

3 ONS-National Power System Operator.

${ }^{4}$ CBHSF-São Francisco River Basin Committee.
} 
Table 1 Installed capacity of electric sources in Brazil's Northeast region in 2017 (source: [51])

\begin{tabular}{lcr}
\hline Electric sources & Installed capacity (MW) & $\%$ \\
\hline Hydropower plants (>30 MW) & $11,975.00$ & 41.4 \\
Wind power plants & 8017.00 & 27.7 \\
Thermoelectric plants_fossil fuels & 7006.20 & 24.2 \\
Thermoelectric plants-biomass & 1830.67 & 6.3 \\
Small hydropower plants (>5 MW,<30 MW) & 105.50 & 0.4 \\
Photovoltaic solar power plants & 15.00 & 0.1 \\
Total & $28,949.37$ & 100.0 \\
\hline
\end{tabular}

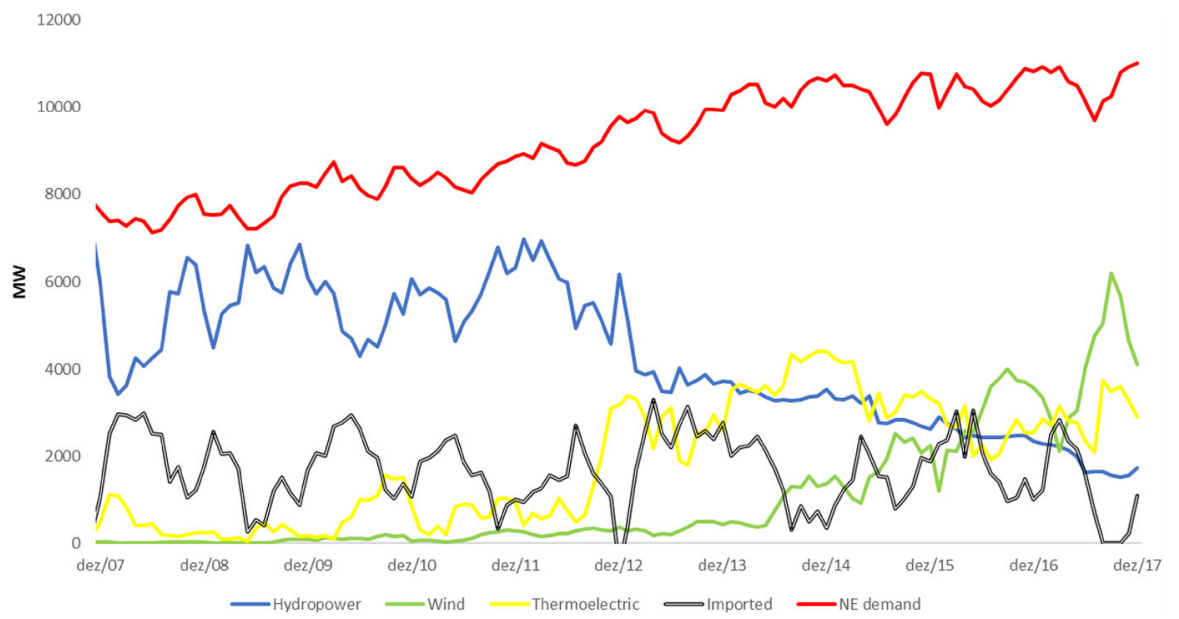

Fig. 2 Electricity generation in Brazil's Northeast. Source: ONS [51]

generation, investing in other sources of electricity generation and defining clear rules for the reservoirs' management. Another point which must be highlighted regarding the electricity sector is that the NE is not self-sufficient in electricity generation, i.e. the demand is usually higher than the generation and therefore it is necessary to import electricity from other regions of the country.

The Brazilian Water Act prescribes to build consensus in favor of the management of reservoirs for multiple purposes. ONS, $\mathrm{CEMIG}^{5}$ and $\mathrm{CHESF},{ }^{6}$ who are responsible for the management of the biggest reservoirs in the basin, are primarily aiming at optimization of hydropower generation, and thus their actions are not fully coordinated with the actions of ANA and CBHSF. Siegmund-Schultze et al. [66] present the challenges of water governance in the basin and point out that shared responsibilities are not clear due to administrative overlaps and that governmental agencies are still not ready to share responsibilities. Therefore, water allocation remains a difficult challenge for users.

\footnotetext{
${ }^{5}$ CEMIG-Minas Gerais Energy Company.

${ }^{6}$ CHESF-São Francisco Hydropower Company.
} 
Bridging the gap in the electricity generation of the NE, and the São Francisco River Basin in particular, is at the center of a growing debate not only among academics but also among stakeholders of the sector, society, and policy makers. Sustainable development aims at using resources to satisfy current needs along with those of future generations [77]. A sustainable water-energy system, for instance, in the São Francisco River Basin, embodies also the concepts of self-sufficiency, electrical efficiency, electricity saving and the expansion of renewable energy use. Furthermore, the interactions between water and energy involve complex and multiple variables for the management of reservoirs, practices of good water governance, and factors unleashed by climate change which have even more intensified the difficulties in water sharing among diverse users. A sustainable electricity system in a river basin context may have the final objective of securing equilibrium between social, economic and environmental activities which are related to water [2, 31]. According to the watershed management plan [17] $76 \%$ of the granted flow in the basin is for agriculture; in addition, there was a 136\% rise in irrigated areas between 2004 and 2013 and a rising tendency in the future. Moreover, further pressure on the water resources comes from the large water diversion project (São Francisco river transposition), whose operation was starting during the writing of this paper. Thus, practices that seek to reduce water use conflicts and assure future electricity-generating reserves in the region are increasingly important. Furthermore, these practices should be able to deal with water scarcity and reduce the negative effects of using fossil fuels. It becomes clear that the decision in favor of a sustainable water-energy system is an approach with multiple objectives, sometimes in conflict with each other, due to the rising complexity of social, technological and environmental dimensions and economic factors $[2,16,33]$ and is ultimately embedded in a wider societal context and nexus of resource use and conservation [67].

Thus, a multi-criteria tool would be promising to support decisions capable of justifying choices in a clear and conscious way [16]. The aims of this paper are: (a) structuring the problem, (b) simulating scenarios to support the selection of alternatives, with a focus on the diverse management priorities of the reservoirs to reduce conflicts, and eventually answering the following question: Will the Northeast's electricity system be able to meet demand if the current drought scenario keeps happening or persists?; and (c) defining criteria and sub-criteria to analyze the water-energy sustainability of the river basin.

\section{Materials and methods}

Taking into consideration that water management and hydropower generation are linked, the methodology of this paper aims to support electricity planning through tools which encourage good hydro-energetic governance. Multi-Criteria Decision Analysis (MCDA) is one of the most frequently used models in the energy sector and in the decision-making for the management of water [72]. The procedural steps to model the MCDA are represented in Fig. 3. Essentially, the process is divided in two phases: (1) the structuring phase (scenario generation) and (2) the phase of MCDA model selection, application and results evaluation (scenario evaluation). This paper covers 


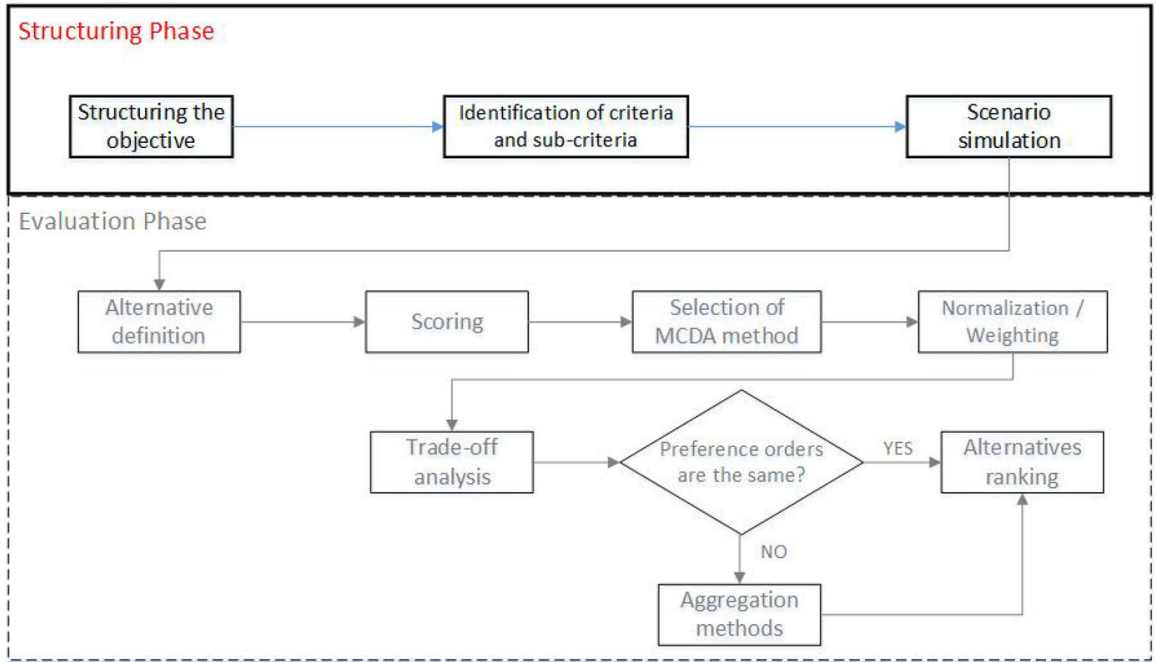

Fig. 3 Phases of MCDA, the steps in black are covered by this paper. Adapted from Ribeiro [60]

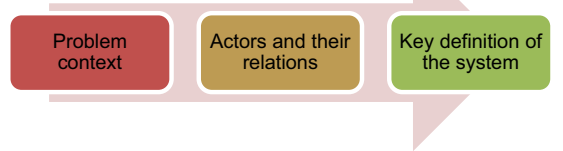

Fig. 4 Phases in the structuring of the problem, leading to the identification of the objective

the phase of the model structuring, which includes the structuring of the objective, the selection of relevant criteria and sub-criteria and the simulation of scenarios.

\subsection{Objective structuring}

During the last decades four methods of problem structuring have become particularly known: (1) Strategic Options Development and Analysis (SODA), (2) Soft Systems Methodology (SSM), (3) Strategic Choice Approach (SCA) and (4) Value-Focused Thinking (VFT) [3]. We opted for the SSM as it is a straightforward method to clarifying the problem context, identifying actors/stakeholders and their relations and capturing the essence of the system (Fig. 4).

The rich picture is a diagram that depicts issues (such as problem context, actors and their relationships) to visualize the complex situation from all its many perspectives $[3,19,42]$. For this purpose, papers resulting from workshops and public consultations performed by the CBHSF in the entire river basin in 2015 and 2016 [17] were consulted. The key definition is a short textual description that captures the nature of the system, clarifies what is required to be addressed and identifies the system in which the subsequent analysis will be done. The formulation of the key definitions of the system is related to the mnemonic method CATWOE. CATWOE can be interpreted 
as Customer, Actor, Transformation, Worldview, Owner, and the Environment [46]. Almeida et al. [3] define the CATWOE elements as described below:

- Customers: who are the victims and/or beneficiaries of the system transformation?

- Actors: who will execute the activities for the system transformation?

- Transformation: which transformations will be performed through the activities?

- Worldview: perception or worldview, i.e. the reason to realize the transformation.

- Owner: who has the power to modify or stop the transformation?

- Environment: cultural, social, environmental or political restrictions which affect the system.

The key definition of the system (CATWOE questions) was done through interviews with specialists who act directly on water resources management in the São Francisco River Basin. For example, the technical director of the São Francisco River Basin Agency was one of these interviewees. It was necessary to clarify for them which were the elements of the analysis, such as: which system should be transformed (São Francisco River Basin), the process through which the system is undergoing, and what activities should be undertaken to transform the system. Subsequently, the final questions were elaborated.

\subsection{Identification of indicators}

The methodology employed for the criteria and sub-criteria identification and the participatory decision process was adapted from Cloquell-Ballester et al. [18]. Three stages were used in the procedure of criteria and sub-criteria definition: (a) selection and pre-check of criteria and sub-criteria, (b) interviews with professionals and scientists, and (c) aggregation of results (Fig. 5).

\subsubsection{Selection and pre-check of criteria and sub-criteria}

The criteria and sub-criteria selection stage started with a bibliographic review to identify the indicators most frequently used for a multi-criteria approach in the hydroelectric sector. The criteria and sub-criteria more widely used by actors cited in the references were pre-selected according to the scheme shown in Fig. 5. The process of pre-selection analyzed whether the criteria could be directly used for the proposed objective, whether it would be necessary to adapt them or whether the creation of new criteria not yet addressed for the specific case in discussion would be necessary.

\subsubsection{Interviews with stakeholders/actors}

The following questions guided the selection of stakeholders/actors for subsequent administration of the interviews, as suggested by Almeida et al. [3]:

Stakeholders/actors and their needs:

I. Who are the decision-makers?

II. What are the roles of the stakeholders/actors in the problem context?

III. Which stakeholders are affected? 


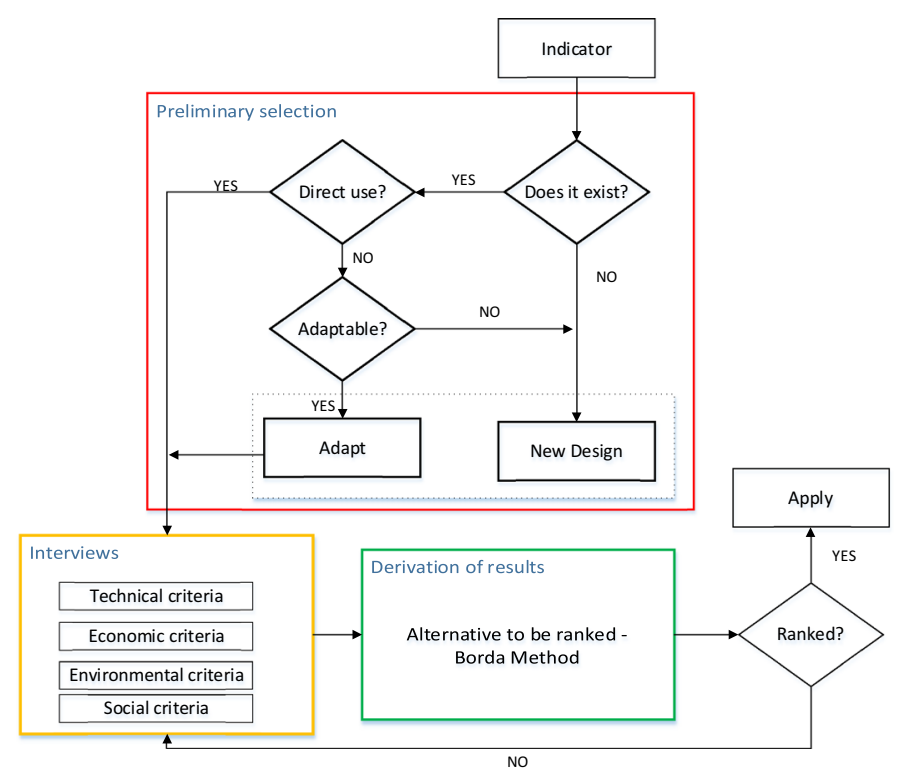

Fig. 5 Process of criteria and sub-criteria selection for MCDA. Adapted from Cloquell-Ballester et al. [18]

IV. Did the stakeholders/actors collaborate in previous situations?

Knowledge level:

I. How familiar with the problem context are the stakeholders/actors?

II. Which aspects of the problem context are stakeholders/actors aware of?

III. How will knowledge sources be obtained during the process?

Possibility to use support tools:

I. How much time and effort can group stakeholders/actors invest in the process?

II. Which methodological tools are best aligned with the needs and possibilities (workshops, video conferences, online search forms, etc.)?

Presence of uncertainties:

I. How much is known about the different decision alternatives and their consequences?

II. Can the uncertainties be reduced?

Applying the listed questions, 35 institutions were selected amongst private and public companies in the electricity sector, institutions related to water and environment management, as well as universities. The aim was to select the stakeholders/actors from each institution who had direct relation and familiarity with each of the four main groups of criteria: technical, economic, environmental and social. Around 100 stakeholders/actors were pre-selected for interviewing, and 59 of them finally participated (Table 2). The participants worked for the following companies, agencies and institutions related to water and electricity management: Peixe Vivo Agency (AGP), ANA, 
Table 2 Summary of the interviewed group

\begin{tabular}{ll}
\hline Criterion & Number of respondents \\
\hline Technical & 22 \\
Economic & 14 \\
Social & 11 \\
Environmental & 12 \\
Total & 59 \\
\hline
\end{tabular}

Pernambuco Agency for Water and Climate (APAC), CHESF, São Paulo Energy Company (CESP), Energy Research Company (EPE), Tietê Energy Generation Company (AES), Energy Generation Company (EDP), Energy Metropolitan Company of São Paulo (EMAE), Energy Generation Company ENGIE Brazil, Teles Pires Hydropower, Enel Green Power (EGP), State Institute of Environment and Water Resources of Bahia (INEMA-BA), Light Energy, Neoenergia, ONS, Environment Secretary of Minas Gerais and Pernambuco States (SEMA), Federal Universities (Minas Gerais, Bahia, and Pernambuco states), and Santo Antônio Energy Company (SAE). It is important to highlight that, due to the complexity and required level of knowledge, the selected stakeholders/actors were all professionals who had direct relation with the electricity sector. The other actors of the basin, such as water users and civil society, were not consulted.

The interviewees represented views from the regional and the national scale. This makes sense, since the electricity sector is organized in a National Integrated System (SIN). ${ }^{7}$ The inquiries were made through personal interviews by video conference, telephone and online forms. At the start of each interview a short introduction was made about the aim of the research and the facilitator, and some questions were asked to verify the level of knowledge of the interviewee with the problem and decisions at stake. The interviews were conducted with 59 stakeholders, which were asked to define their personal ranking of the sub-criteria (Appendix 1) to be used in structuring the multi-criteria model in support of the electric sector planning.

\subsubsection{Aggregation of results}

The results of single interviewees' responses were grouped. Forman and Peniwat [55] presented two ways to aggregate the results of a decision-maker group. The method Aggregation of Individual Judgments (AIJ) is used when individuals in a group act in harmony and there is an agreement in the aggregation of individual judgments. In this case the individual identities are lost in the process and the group behaves as a new and unique individual. Another method considers a heterogeneous group, which does not show agreement and common goals, making group consensus difficult. In this case it is recommended to use Aggregation of Individual Priorities (AIP). Almeida et al. [3] differentiate between two types of aggregation rule-making, one with the participation of a supra-decision-maker who imposes aggregation rules and, when

\footnotetext{
7 SIN-Interconnection of electrical systems of all the regions in Brazil. It consists of four sub-systems: South, Southeast/Central-West, Northeast, and North.
} 
appropriate, establishes the condition for the aggregation of the decision-makers group; and a second, with a collaborative decision group which develops its own aggregation rule. We opted to use the aggregation rule-making involving a supra-decision-maker, i.e., the paper lead author.

The interviewees were assigned to four sub-groups in order to analyze the preference for each technical, economic, environmental and social criterion separately; i.e., each decision-maker was assigned to a group according to his/her expertise and field of work. Through search forms the order of relative importance of each criterion was asked for the development of a MCDA model which could give support to strategic decisions in the electricity sector. In this way, each sub-group appeared more homogeneous and therefore the grouping of judgments was harmonized and the sub-group became a "new" individual acting as only one (AIJ method). Hence the individual priorities of each decision-maker were not especially relevant. The ranking methodology employed was the Borda method $[3,49]$. The Borda method consists in ranking each sub-criterion of each decision-maker in a preference order, by assigning points in such a way, that the sub-criterion of preference 1 obtains more points and the less preferable criterion receives fewer points. Almeida et al. [3] suggest the adoption of a parameterization assigning to the worst alternative (lesser preference) the value a, to the second-worst the value $a+b$, to the third-worst $a+2 b$ and so on. Hence the ranking of results runs in decreasing order, that is, from the criterion with the most points to the one with the fewest points. The method was chosen due to its simplicity and robustness in application. For the ranking, the sum of points that each sub-criterion obtained from all the decision-makers of the group was applied. Thereby, the result is a combination of the judgments of the different interviewees in order to obtain, for each sub-criterion, the most adequate final score for the multi-criteria model.

\subsection{Development of scenarios and priority vectors}

The development of scenarios is a widely used methodology, which is employed to include uncertainties about possible future developments in decision making [43, 56]. Five scenarios for reservoir management based on the latent conflicts between the electricity sector and the other sectors' users were elaborated. The development of these scenarios aimed to set up suitable alternatives to be used in MCDA. The scenarios are further explored in Sect. 2.3.2. The simulated scenarios analyze the effects of climate change between 2021 and 2050 on hydropower generation, water provision for irrigation/supply (agriculture, domestic water supply, livestock and industrial supply; and fishing and fish-farming), navigability of the São Francisco River and support to the local ecosystem. The regional eco-hydrological model SWIM (Soil and Water Integrated Model, [8]) was used. Some adaptations for the application of SWIM in Brazil had already been undertaken earlier [6] since it was conceived to be applied in some regions of Europe [29]. The calibration and validation of the model was carried out for 18 gauges located in the basin, and reservoir management was implemented in the model for eleven reservoirs. Overall, 58 water users were included. They were large individual irrigation users or a mix of different users, i.e. aggregations of smaller users. Twenty-nine of these users withdrew water from the São Francisco main river 
and the other 29 from tributary rivers (see Fig. 1). In the Upper São Francisco the main water demands are for irrigation and industry; in the Sub-Middle and Lower São Francisco the main use is for irrigation. To quantify monthly average water demand of each user, data from ANA, IGAM ${ }^{8}$ and CHESF were used. Furthermore, some control points with minimal flows along the basin were defined (Fig. 1), based on data from ONS [50]. These points limit and regulate users' water withdrawal depending on the priority setting in the scenario. The minimal flows of each control point and scenario are detailed in Table 5 (Sect. 2.3.2).

Stakeholders evaluated the results returning to the developments and simulations of the different scenarios (priority setting). To this end, a decisive method based on the Pairwise Comparison method was developed. In this method the process of alternatives comparison can be modeled in a hierarchical structure [25]. According to Lombardi et al. [40] the method may be divided in six stages: (1) objective definition, (2) elaboration of hierarchical structure, (3) pairwise comparison of criteria and alternatives by decision-makers using the Saaty scale [61, 62], (4) definition of comparison matrices and their priorities vectors, (5) consistency analysis and (6) normalization of results. The hierarchical method sketched before starts from the top with the objective of the decision, which relates to the more adequate allocation of water in the São Francisco River Basin according to users and stakeholders (Fig. 6). In the lowest level, the alternatives belonging to the criteria social equity, environmental sustainability and economic efficiency are shown [75]. They are based on the perspectives of water use presented by UNESCO and are introduced [75] in accordance with the activities that exist in the basin as presented in the recently updated São Francisco River Basin Management Plan (PBHSF) [17]. As illustrated in Fig. 6, a hierarchy does not need to be complete; an element in a certain level does not need to be used as an attribute for all the levels below [61]. When this occurs, the hierarchical structure is called "incomplete" and may be divided into sub-hierarchies, which only have one criterion in common at the top [64]. In this case the process is called Incomplete Pairwise Comparison [28] and it is also used to reduce the number of comparisons, since a structure that contains many alternatives requires several comparisons. In the example described in this paper the relative importance was analyzed only among alternatives A1-A4 concerning the social criterion, alternatives A5-A8 for the economic criterion and alternatives A9 and A10 with reference to the environmental criterion. Therefore, there were no comparisons, for instance, between alternative A1 of the social criterion and alternative A7 of the economic criterion. It was accepted that the understanding of the water allocation priority using Incomplete Pairwise Comparison would save substantial time and the objective would be achieved in the same way as using Complete Pairwise Comparison [28].

In the development of comparison matrices, each element of a superior level is used to compare the elements in the level immediately below it. Criteria are compared among themselves, by the degree of importance in achieving the goal. That is, four matrices were calculated in order to find the priority vectors among the criteria, and the priority vectors among the alternatives for each criterion separately. Table 3 presents the matrix "Criteria vs. Goal" (Cij) which shows the judgments among the

\footnotetext{
8 IGAM-Water Management Institute from Minas Gerais.
} 


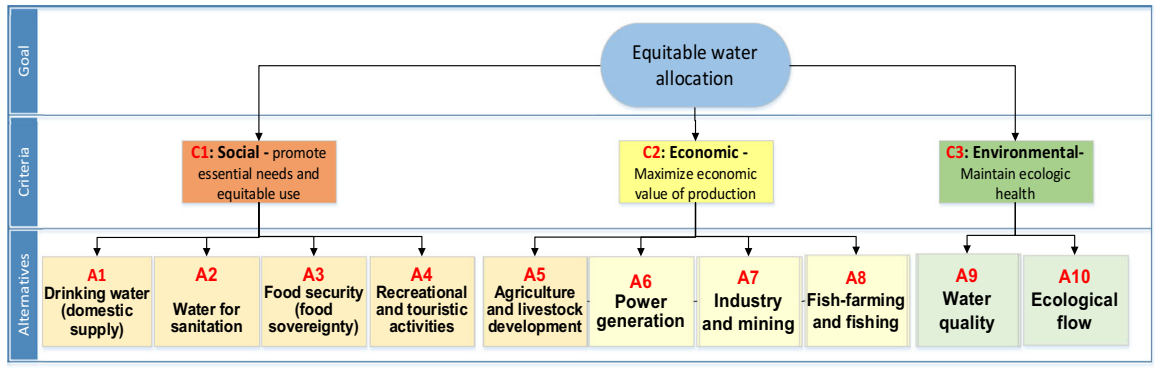

Fig. 6 Incomplete hierarchy with alternatives contributing to a single criterion

Table 3 Comparison matrix “Criteria vs. Goal” and criteria priority vector

\begin{tabular}{lllll}
\hline Goal & $\mathrm{C}_{1 \text { (Economic) }}$ & $\mathrm{C}_{2 \text { (Environmental) }}$ & $\mathrm{C}_{3 \text { (Social) }}$ & Priority vector $\left(\mathrm{Vc}_{\mathrm{i}}\right.$ ) \\
\hline $\mathrm{C}_{1 \text { (Economic) }}$ & 1 & $\mathrm{C}_{12}$ & $\mathrm{C}_{13}$ & $0.4454 \mathrm{Vc}_{\mathbf{1}}$ \\
$\mathrm{C}_{2}$ (Environmental) & $\mathrm{C}_{21}$ & 1 & $\mathrm{C}_{23}$ & $0.3058 \mathrm{Vc}_{\mathbf{2}}$ \\
$\mathrm{C}_{3 \text { (Social) }}$ & $\mathrm{C}_{31}$ & $\mathrm{C}_{32}$ & 1 & $0.2488 \mathrm{Vc}_{\mathbf{3}}$ \\
\hline
\end{tabular}

$C_{i}$ criterion, $C_{i j}$ pairwise comparison judgments between criteria $\mathrm{Ci}$ and $\mathrm{Cj}, V c_{i}$ criteria priority vector

Table 4 Comparison matrix "Alternatives vs. Economic Criteria" and alternatives priority vector

\begin{tabular}{llllll}
\hline Economic criteria & $\mathrm{A}_{5}$ & $\mathrm{~A}_{6}$ & $\mathrm{~A}_{7}$ & $\mathrm{~A}_{8}$ & Priority vector $\left(\mathrm{Ves}_{\mathrm{i}}\right)$ \\
\hline $\mathrm{A}_{5}$ & 1 & $\mathrm{~A}_{56}$ & $\mathrm{~A}_{57}$ & $\mathrm{~A}_{58}$ & $\mathrm{Ves}_{5}$ \\
$\mathrm{~A}_{6}$ & $\mathrm{~A}_{65}$ & 1 & $\mathrm{~A}_{67}$ & $\mathrm{~A}_{68}$ & $\mathrm{Ves}_{6}$ \\
$\mathrm{~A}_{7}$ & $\mathrm{~A}_{75}$ & $\mathrm{~A}_{76}$ & 1 & $\mathrm{~A}_{78}$ & $\mathrm{Ves}_{7}$ \\
$\mathrm{~A}_{8}$ & $\mathrm{~A}_{85}$ & $\mathrm{~A}_{86}$ & $\mathrm{~A}_{87}$ & 1 & $\mathrm{Ves}_{8}$ \\
\hline
\end{tabular}

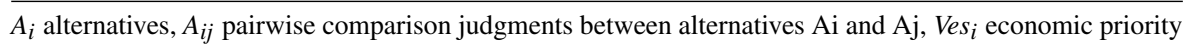
vector

suitable criteria related to water allocation in the basin and their related priority vectors (Vci). Table 4 presents the comparison matrix "Alternatives vs. Criteria" related to the economic criterion (Eij) and its priority vector. The matrices "Alternatives vs. Criteria" related to the social (Sij) and environmental (Aij) criteria were elaborated in a comparable way. All the mathematical processes were accomplished employing the Super Decision ${ }^{\circledR}$ software developed by the Creative Decisions Foundation [20]; the stages of consistency analysis and normalization of results were also calculated with the support of the software. The consistency of the achieved solution must be tested according to Saaty [63] by the following procedures: (a) initially the maximum eigenvalue $\left(\lambda_{\max }\right)$ is estimated through Eq. (1), where $\mathrm{W}$ is a normalized eigenvector calculated by adding the columns of the comparison matrices and $\mathrm{T}$ is the sum of the columns of the matrices, (b) the consistency index $(C I)$ is calculated by Eq. (2), where $\mathrm{N}$ represents the order of the matrix, (c) finally the consistency ratio $(C R)$ is calculated by Eq. (3), where CA is a the consistency index of a random matrix, introduced by Garni et al. [25] and Lombardi et al. [40]. 


$$
\begin{gathered}
\lambda_{\max }=T \times W \\
C I=\frac{\left(\lambda_{\max }-N\right)}{(N-1)} \\
C R=\frac{C I}{C A} .
\end{gathered}
$$

If the consistency ratio is less than $0.1(\mathrm{CR}<0.1)$ the judgments can be considered consistent. Otherwise the decision-makers must re-evaluate the elements belonging to the same hierarchical level. Thus, the results that presented a consistency index higher than 0.1 had their respective interviewees excluded from the research. The methods Pairwise Comparison (frequently used in the multi-criteria method Analytical Hierarchy Process-AHP) and Incomplete Pairwise Comparison do not only have the benefit of analyzing the consistency of judgments, but they are also recommended for complex issues which involve high uncertainties and conflicts, and for groups with divergent interests and controversial visions $[2,5]$.

In this case study, the judgments for the comparison matrices were obtained through interviews, which were performed with actors of diverse sectors in the São Francisco River Basin. The interviews included questions to support the "Criterion vs. Goal" matrix, e.g. "How many times is the economic criterion of water more or less important than the social and environmental criterion for a more adequate water allocation in the basin?", and to support the "Alternatives vs. Criteria" matrices, e.g. "How many times is domestic supply more or less important than sanitation under the social viewpoint?", or "How many times is hydropower generation more or less important than irrigated agriculture under the economic viewpoint?". See further questions in Appendix 2. In this way, comparison between criteria pairs and alternatives was made one by one, employing the scale of Saaty [63], which uses integers between 9 (when the alternative is extremely important in relation to the other) and 1 (when the alternative is equally important to the other). In case of the alternative being less important the scale varies from -1 to -9 (values < 1). For more information see Saaty [63] and Liu et al. [39].

The group of interviewees in this exercise was formed by 47 volunteers, who were recruited through announcements during sessions of the "I Scientific Conference of the São Francisco River Basin" in 2016 in Petrolina (Pernambuco). The event was a convenient moment to approach stakeholders from different parts of the river basin, from different sectors/disciplines, and administrative levels, as well as governmental and non-governmental organizations. A certain overlap of the participants with the aforementioned group of 59 interviewees (Sect. 2.2.2) cannot be ruled out since the questionnaire was administered anonymously at the conference. Due to high heterogeneity the AIP method was used and individual priorities were considered for each stakeholder. That is, the procedure was conducted individually for each stakeholder, obtaining in this way a different priority ranking for each decision-maker. Altuzarra et al. [4] and Saaty [65] suggest that the final result of priorities should be calculated using the geometric average, as it offers an effective way of aggregating the judgments of people with different perspectives. However, the geometric average is not appropriate to represent general priorities for incomplete hierarchy; thus, in this case the arithmetical average was applied [55]. The same supra-decision-maker decided 
over the aggregation of single results to group decisions and there was no weighting established among the interviewees.

\subsubsection{Climate models and projection of climate change}

Climate change is affecting water balance and water demand. Montenegro and Ragab [44] highlight that these changes require new management strategies and risk mitigation in water resources management. In regions with low and/or poor distribution of precipitation these changes bring negative effects upon the many uses [36] and hydropower generation is one of the directly affected activities. The Intergovernmental Panel on Climate Change (IPCC) presents climate change projections and carbon emission pathways-Representative Concentration Pathways (RCPs). The RCPs are based on projections of the global economic activity, energy sources used, population growth and other socio-economic factors until 2100 [76], and serve as an input for the existing global climate models [69]. Four RCPs were published by the IPCC-RCP2.6, RCP4.4, RCP6.0 and RCP8.5-which go, respectively, from the most optimistic situation to the most pessimistic. This paper has selected two projections for the simulation of scenarios, namely RCP2.6 and RCP8.5. The former presupposes that through a severe political intervention greenhouse gas emissions are reduced almost immediately, leading to a slight reduction compared to current levels by 2100 [79]. RCP8.5 assumes continuous population growth and slow technological development, which results in elevated emissions of carbon dioxide [59].

Results of the global climate model MIROC (Model for Interdisciplinary Research on Climate) for RCP2.6 were used in this study to develop the five scenarios of Set A (see Sect. 2.3.2). The results of the global climate model HadGEM for RCP8.5 were used to define the scenarios of set B, except for the scenario called "Drought". The water management in the drought scenario presents an adaptation to periods of prolonged drought as experienced between 2012 and 2017. This type of climatological conditions is more or less normal under Set A (dry scenario). Therefore a water management as realized over the last years was tested in Set A. This option was not implemented for Set B, since such extreme/prolonged droughts do not occur in this set of scenarios. Although RCP2.6 is the lowest emission scenario, the MIROC model suggests strong droughts in the São Francisco River Basin, with MIROC for RCP8.5 giving only somewhat lesser droughts. RCP8.5 simulated with HadGEM projects a rather wet future events, with HadGEM for RCP2.6 giving comparable results. Climate scenario data of the Coupled Model Intercomparison Project Phase 5 (CMIP5) were used as global climate projections, statistically downscaled and correcting bias for the river basin [30].

\subsubsection{Water management scenarios}

The scenarios are developed in order to present and compare effects of different priority settings for minimum discharges and reservoir management. Each scenario is an extreme in terms of clearly prioritizing one specific use or feature. Hereinafter a brief thematic description of the simulated scenarios is given, while the modeled minimum flows at specific control points are to be found in Table 5. 
Table 5 Definition of control points, minimum flows and discharges along the São Francisco River

\begin{tabular}{|c|c|c|c|c|c|c|}
\hline \multirow[t]{2}{*}{ Control points } & \multirow[t]{2}{*}{ Scenarios } & \multicolumn{5}{|c|}{ Minimal flow $\left(\mathrm{m}^{3} / \mathrm{s}\right)$} \\
\hline & & Hydropower & Irrigation/supply & Drought & Navigation & Ecosystem \\
\hline Pirapora & I & 80 & 80 & 80 & 500 & 420 \\
\hline $\begin{array}{l}\text { Pirapora-São } \\
\text { Romão }\end{array}$ & II & 150 & 100 & 100 & 500 & 420 \\
\hline $\begin{array}{l}\text { São } \\
\text { Romão-Jaíba }\end{array}$ & III & 200 & 150 & 150 & 500 & 420 \\
\hline $\begin{array}{c}\text { Jaíba (Matias } \\
\text { Cardoso) }\end{array}$ & IV & 315 & 315 & 315 & 500 & 420 \\
\hline Jaíba-Sobradinho & $\mathrm{V}$ & 400 & 350 & 350 & 500 & 420 \\
\hline $\begin{array}{l}\text { Sub-Middle } \\
\text { São } \\
\text { Francisco } \\
\text { (Sobradinho- } \\
\text { Xingó) }\end{array}$ & VI & 1100 & 900 & 700 & 1300 & $\begin{array}{r}\text { Environmental } \\
\text { flow (AIHA) }\end{array}$ \\
\hline $\begin{array}{l}\text { Lower São } \\
\text { Francisco } \\
\text { (downstream } \\
\text { Xingó) }\end{array}$ & VII & 1100 & 900 & 700 & 1300 & $\begin{array}{r}\text { Environmental } \\
\text { flow (AIHA) }\end{array}$ \\
\hline Main reservoirs & Disch & $\operatorname{arges}\left(\mathrm{m}^{3} / \mathrm{s}\right)$ & & & & \\
\hline Três Marias & 500 & 500 & 200 & 500 & 500 & \\
\hline Sobradinho & 1300 & 1300 & 700 & 1300 & Environme & ital flow (AIHA) \\
\hline Itaparica & 1300 & 1300 & 700 & 1300 & Environme & tal flow (AIHA) \\
\hline
\end{tabular}

Sources: $[42,50,53]$

"Hydropower" scenario The first scenario, "Hydropower", mirrors the business as usual from the viewpoint of the hydropower companies and the electricity sector, which aim at maximizing hydroelectricity generation within a national grid system. In this scenario minimum flows presented by ONS [50] for all the control points were used. The users will only be able to withdraw water from the São Francisco River when flows remain above the mentioned minimum flows at each control point.

"Irrigation/supply" scenario The "Irrigation/supply" scenario puts the needs of water users on top of priorities. While the reservoir management reflects the business as usual, i.e. is focusing on hydropower generation, the minimum flows for water users are lowered (see Table 5), enabling water withdrawals even at low water levels. This means, e.g., that the large irrigation projects in the Sub-Middle São Francisco (see Fig. 1) can withdraw more water leading to reduced inflow to the Itaparica Reservoir.

"Drought" scenario The "Drought" scenario is a special case since it is not prioritizing a specific user group, but analyzing the effects of an adapted water management to prolonged dry periods that might repeat more often in the future due to climate change. 
“Navigation" scenario ONS [50] and PBHSF [17] define procedures and minimum flows to meet the navigation requirements in some sections of the São Francisco River, and emphasize the importance of navigation in many sections of the river's main course. In the city of Pirapora (Minas Gerais) at the Upper São Francisco the minimum flow for navigation of the riverside population in regular rainy years should be $100 \mathrm{~m}^{3} / \mathrm{s}$. In the section between the cities of Pirapora and Juazeiro (Bahia) in the Middle São Francisco, navigation can be hampered by the possibility of stranding of vessels [50]. Therefore in an agreement between CODEVASF $^{9}$ and CEMIG, the flow downstream of Três Marias Reservoir should be at least $500 \mathrm{~m}^{3} / \mathrm{s}$, promoting adequate depth for vessels in these sections. Downstream of the Sobradinho Reservoir the minimum flow which should be maintained not to cause damage to activities is $1300 \mathrm{~m}^{3} / \mathrm{s}$ [50]. Based on these pre-established limits, the "Navigation" scenario was simulated with the primary purpose of supporting navigation in the river, that is, other users will only be able to withdraw water from the river if the flows are above the minimum limit in the control points shown in Table 5 and represented in Fig. 1.

"Ecosystem" scenario A study in the Lower course of the São Francisco River [42] emphasized that (a) the loss in fish diversity reached approximately $50 \%$, i.e., species which in the past were very important for fishing activities are currently rare; (b) aquatic habitats were severely altered with the silting up of the river; and (c) the alterations in the fish population are probably due to a combination of factors which include control and regularization of flows. According to Medeiros et al. [42] there must be, in a long term, a restoration of the natural conditions of the river for the maintenance of the ecosystem. Therefore the "Ecosystem" scenario adopts minimum flows to support the riverine ecosystem (Table 5).

\subsection{Hydrological model}

The climate projection data are used to drive the eco-hydrological model SWIM (Soil and Water Integrated Model, introduced by Krysanova et al. [38]) under scenario conditions. SWIM calculates hydrological processes, natural vegetation, water allocation, e.g. for irrigation and domestic supply, and reservoir management, including hydropower generation, at the river basin scale on a daily time-step.

The reservoir module is a conceptual representation of storage-release processes based on three management options, to which the reservoirs are assigned according to their operation policy: (1) the objective is the minimum discharge downstream, considering the minimum and maximum volumes of the given reservoir for each month; (2) daily release based on hydropower generation demand, considering the minimum and maximum volumes of the given reservoir for each month; other restrictions can be included by introducing for example daily minimum or maximum discharges; (3) daily release based on the water level of the reservoir. For the large reservoirs included in the study option (2) was applied.

The water allocation module (WAM) of SWIM was applied to allocate water to users. The WAM allows assigning minimum flow requirements at the withdrawal

${ }_{9}$ CODEFASF-Development Company of the São Francisco Valley. 


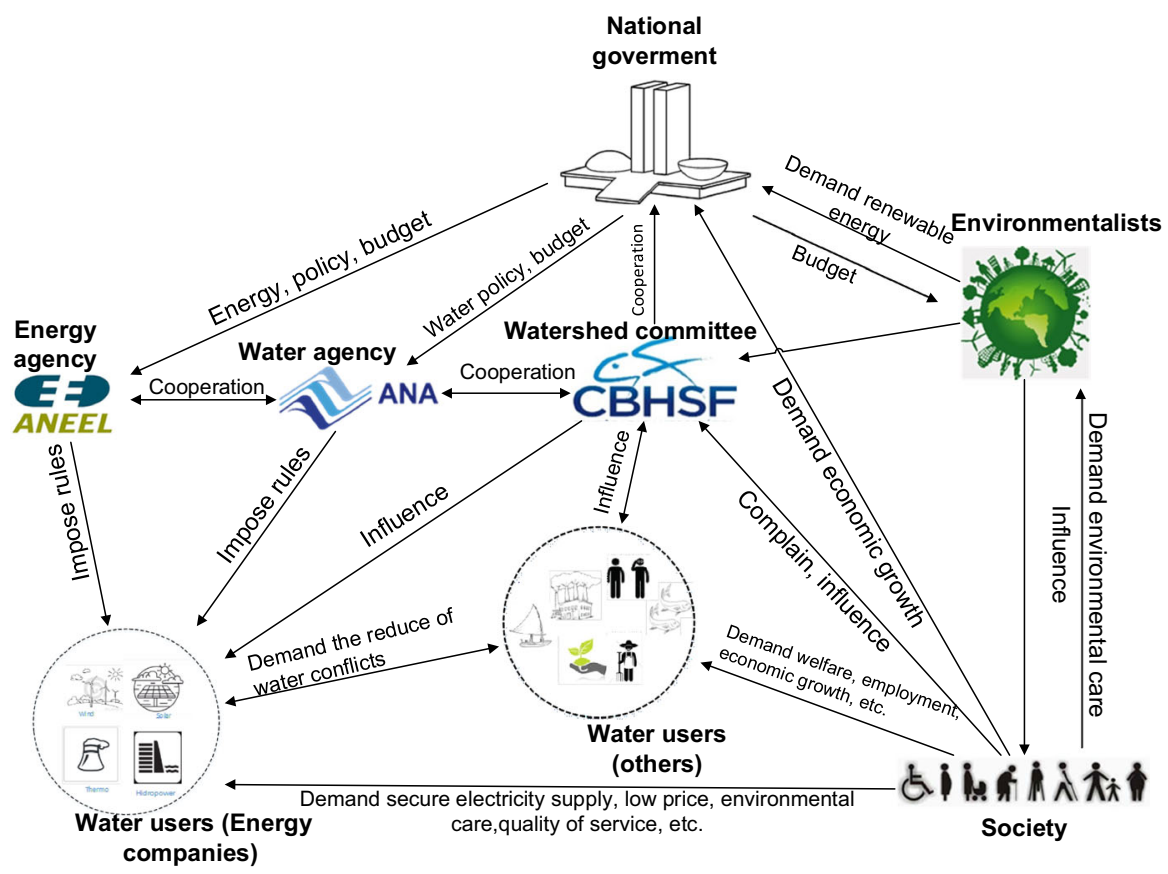

Fig. 7 Relations between major actor groups of the electricity sector in the São Francisco River Basin (rich picture)

point, and takes efficiency and losses of the water transfer into account. The WAM allows withdrawing the water required by the user, if the assigned minimum flow conditions in the reach are ensured, i.e. only water volumes above the minimum flow can be withdrawn. The simulation results for the given scenarios obtained by applying SWIM are used as input for the MCDA.

\section{Results}

\subsection{Objective structuring}

The main actors in the basin who are directly connected with the electricity sector (Fig. 7) are linked to water allocation (and hence, CBHSF, the watershed committee, appears in a central position), since hydroelectricity was the main source for electricity before the onset of the multi-year drought (Fig. 2). Table 6 shows the reasons, main conflicts, possible solutions and actors involved in the problems that are directly related to the electricity sector in the São Francisco River Basin. The relevant actors identified in the system were: Federal Government (through the Ministry of Mines and Energy - MME) and Energy Research Company —EPE, CBHSF, water and energy 


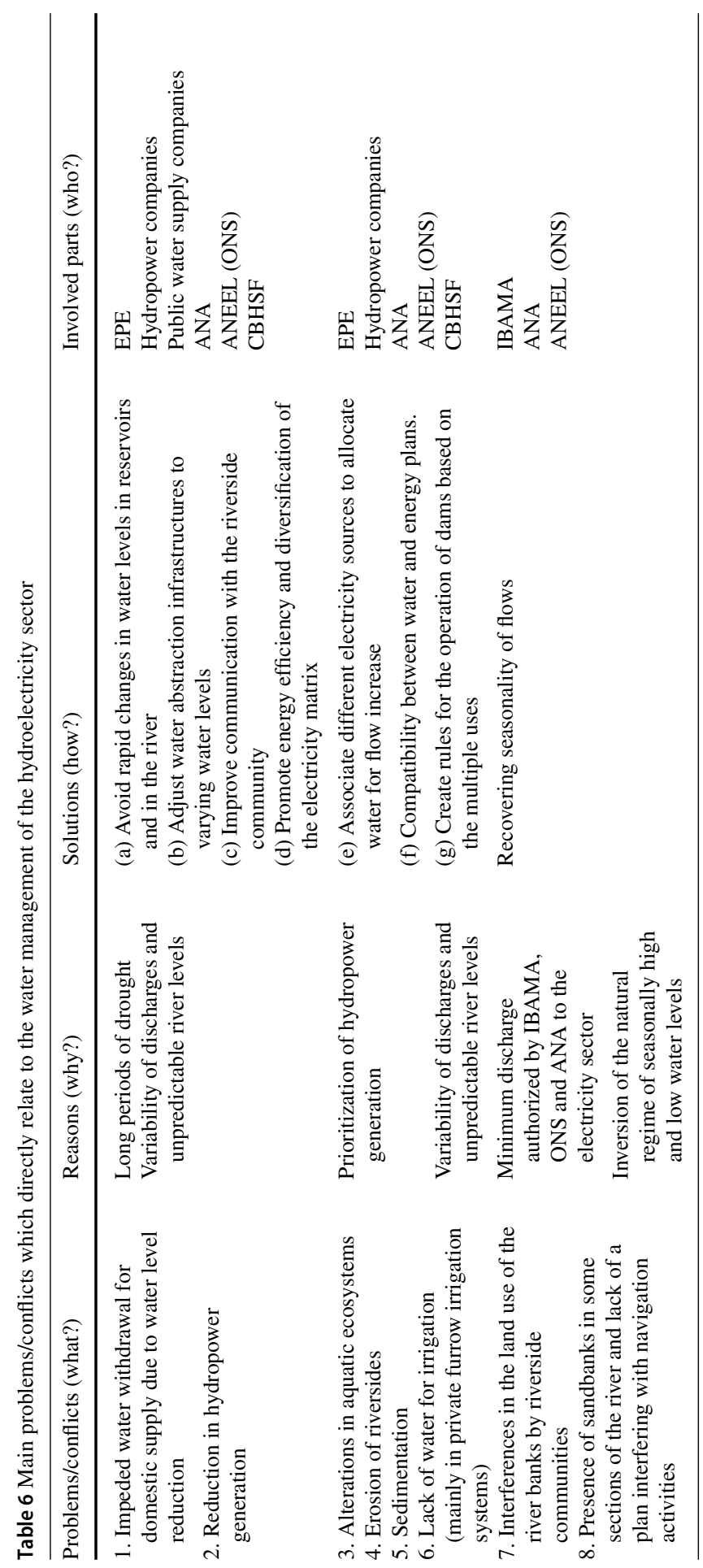


regulatory agencies (ANA, ANEEL ${ }^{10}$ and ONS), energy companies, user sectors (agricultural, domestic, animal and industrial supply; navigation; fish farming and fishing; amongst others), environmental institutions and the civil society (including NGOs and Universities). Many other actors on a local level are also involved in the process, such as state committees of tributary river basins, cooperatives, and state water agencies. However, the main decision-makers who could more directly influence, benefit and/or make use of the multi-criteria model are represented in Fig. 7.

According to the SSM analysis results, which diagnosed the problem context, it becomes clear that there is a growing crisis in the electricity sector in the basin, highlighting the lack of electricity diversification (high water dependency of the electricity sector and necessity to invest in other energy sources); the sequence of long periods of drought; variability and unpredictability of levels and flows in the river and in reservoirs (experienced by the "other sector water users"); necessity of improving the efficiency of hydropower generation (i.e. reducing losses in the generation process); deficiencies in water governance (for instance incompatibilities between water and energy plans and failure in the communication between user sectors and administration levels).

To integrate the findings of the problem structuring, the key definitions of the system under discussion have been developed according to the CATWOE analysis (Table 7). The resulting objective of the multi-criteria modeling is: developing a decision-support model for the São Francisco River Basin in the field of sustainable energy development, to be managed by regulatory agencies and basin committees, in cooperation with the electric companies. This includes searching for alternatives aiming for the harmonization between electricity generation and the water crisis, in order to reduce conflicts, guarantee electricity supply and identify a portfolio of investment options in sustainable electricity sources which positively impact in the regional electricity matrix.

\subsection{Criteria selection}

In the literature review, a total of 28 sub-criteria were selected according to the stages presented in Fig. 5. Seven of them are technical, eight economic, eight environmental and five social (see Appendix 1). Table 8 presents the three most relevant sub-criteria, according to the stakeholders, for each group of criteria defined according to the method of Borda. Some sub-criteria that presented similar characteristics were combined, as suggested by interviewees, to avoid redundancy. For example, the economic sub-criteria about the release of water from reservoirs (Table 8) to meet demands for navigation, electricity generation and agriculture were merged since they both deal with the conflicts between water users (further details in Appendix 1, sub-criteria S12 and S13).

$\overline{10}$ ANEEL—National Electric Power Agency. 
Table 7 Key definitions of the electricity system in the São Francisco River Basin (CATWOE)

\begin{tabular}{lc}
\hline Customers & Civil society, electric companies, crop farmers, fish farmers and fishermen, \\
& industrial sector, public water supply companies (including sanitation), \\
& livestock farmers, riverside communities, tourism and leisure sector, and \\
& environment \\
& Federal government, regulatory agencies, electric companies, and river \\
actors & basin committees \\
Transformation process & To reduce conflicts over water use and reservoir management: guarantee \\
& future electricity supply, improve the coexistence of the electric sector \\
& with water scarcity, stimulate the use of renewable energy sources \\
& (mainly wind, solar and biomass), reduce the dependency of the \\
& electricity matrix on hydraulic sources, secure the ecological flow \\
The harmonization between electricity generation and the water crisis is & possible. This is related to the concept of sustainable energy systems, \\
Worldview & which considers economic, social, technical and environmental factors \\
River basin committee, electricity companies and regulatory agencies \\
(including environmental institutions) \\
Budget constraints, energy consumer market, climate variability, political \\
will, public acceptance of new sources of electricity generation and \\
technological maturity
\end{tabular}

\subsubsection{Hierarchic modeling (incomplete pairwise comparison-ICP)}

Deciding on the most appropriate scenarios in considering the demands of consuming and non-consuming water users is a very difficult task, since the decision of water importance and priorities must also be agreed on by the many actors. Merely a quantitative analysis of water availability for each sector would be too simplistic if it does not take into consideration the opinion of stakeholders involved in the process. Therefore, research was carried out considering 47 participants: $12.8 \%$ from Upper São Francisco, 10.6\% from Middle, 25.5\% from Sub-Middle, 6.4\% from Lower and 48.9\% acting in more than one physiographic region. $41.3 \%$ of interviewees were female, pointing out a certain equilibrium between genders. Most of the interviewees (32\%) were members of institutions, universities, committees and NGOs, followed by the hydropower and agricultural sector. Based on the hierarchic framework presented in Fig. 5 for the IPC method and after the consistency analysis stage, 38 interviews presented consistent answers $(C R<0.1)$. Results indicated that interviewees consider the economic aspect as primary in the process of water allocation, followed by the social and environmental criteria.

In accordance with the results shown in Table 9, the interviewees prioritized the availability of water for crop and livestock farming, since they are the sectors of highest importance for the economic development of the basin, followed by electricity generation (hydropower production). Water quality was ranked first for the maintenance of healthy ecosystems. According to the social functions that water performs in the basin, the interviewees elected access to safe drinking water, followed by water for cultivation of subsistence crops (food security), as the most important aspects for social equity (Table 10). 
Table 8 Primary sub-criteria according to the perspectives of stakeholders

Criterion/sub-criterion Description

Technical

Energy efficiency

Production capacity

Technological maturity

\section{Economic}

Investment cost

Operation and maintenance cost (O\&M)

Timing and magnitudes of reservoir releases

Environmental

Impacts on the ecosystem

Land use and occupation of soils

$\mathrm{CO}_{2}$ emission
Ratio, expressed in percentage, of the quantity of useful energy that can be obtained from an energy source

Quantity of electricity produced by a source throughout a time period, divided by the electricity quantity which it could have produced if it was used in full power during this period

The parameter of technical maturity reflects the level of a determined technology being locally and internationally disseminated and commercially available. It is a sub-criterion with qualitative evaluation scale

The components of investment cost are the purchase of mechanical equipment, technological installations, road construction, engineering services, land cost, and other necessary construction works

Operation and maintenance costs are divided in two sub-categories: fixed and variable. The former are the costs of operation and maintenance per year, which are not related with the quantity of electricity generated by the plant. The latter are directly related to the amount of electricity generated

It highlights the importance of the minimum flow for the transport of products such as soy, corn and cotton (navigation) and to meet the economic activities of agriculture, industry, fish farming and domestic water supply, among others, opposed to release rules optimizing hydroelectricity generation. It is calculated considering the minimum flow required for these activities in a determined period, based on the flows defined by "Inventories of hydraulic operative restrictions of hydroelectric improvements" [50]

This sub-criterion is related to water use conflicts between the electricity sector and the ecosystem. It is calculated based on the demand percentage which considers the minimum flows defined by ONS (2016) and AIHA [42, 53] for the protection of fish population downstream of the reservoirs

Land use represents one of the most critical factors for the plants' location, mostly where human activities are relevant factors and cause environmental pressures. This sub-criterion considers the $\mathrm{m}^{2}$ of occupation per $\mathrm{kW}$ of electricity generated

It contributes to the greenhouse effect and climate change, threatening human and ecosystem health. The sub-criterion analyzes $\mathrm{CO}_{2}$ by $\mathrm{kg}$ emitted per $\mathrm{kWh}$ of electricity generated 
Table 8 continued

\begin{tabular}{ll}
\hline Criterion/sub-criterion & Description \\
\hline $\begin{array}{l}\text { Social } \\
\text { Public acceptance }\end{array}$ & \\
& $\begin{array}{c}\text { Public acceptance expresses the population opinions } \\
\text { related to the electricity systems. It must be noted that } \\
\text { social acceptance is not directly measured and } \\
\text { therefore requires qualitative analysis }\end{array}$ \\
In the process of decision-making the creation of jobs \\
during the implementation of electricity systems are \\
indispensable. This sub-criterion can be quantified by \\
the number of jobs created per unit of electricity \\
generated \\
It exposes the level in which a determined technology \\
results in human lives lost. It is measured \\
quantitatively indicating the normalized number of \\
fatal accidents in power plants, both in the \\
establishment stage and during operations, in specific \\
time periods
\end{tabular}

Table 9 Final ranking of criteria

\begin{tabular}{lllllllllll}
\hline Criteria & D1 & & D2 & D3 & & D38 & \multicolumn{2}{c}{ Final priority } \\
\hline Economical & 0.6483 & $1^{\circ}$ & 0.2500 & $2^{\circ}$ & 0.4286 & $1^{\circ}$ & 0.2500 & $2^{\circ}$ & 0.4454 & $1^{\circ}$ \\
Environmental & 0.1221 & $3^{\circ}$ & 0.2500 & $3^{\circ}$ & 0.1428 & $3^{\circ}$ & 0.2500 & $3^{\circ}$ & 0.2488 & $3^{\circ}$ \\
Social & 0.2296 & $2^{\circ}$ & 0.5000 & $1^{\circ}$ & 0.4286 & $2^{\circ}$ & 0.5000 & $1^{\circ}$ & 0.3058 & $2^{\circ}$ \\
\hline
\end{tabular}

$D_{i}$ decision-makers, Final priority arithmetic mean of the 38 of decision makers answers

\subsection{Simulated scenarios}

\subsubsection{Set A: under a severe climate change projection}

Hydropower generation Under the hydrologic conditions observed before the prolonged drought starting in 2012, the average annual hydropower generation in the river basin was $45,000 \mathrm{GWh}$. According to ONS [50] there was a decrease in the annual average between 2012 and 2016 of approximately 57\%. The simulations of hydropower generation in Set A present very similar results in all the scenarios in the period from 2021 to 2050 (Appendix 3). Climate model MIROC presents high climate variability with a predominance of dry years which is compatible with the current situation of the river basin. It suggests the occurrence of very wet years (upward peaks), and even more very dry years (downward peaks) (Appendix 3). Annual average hydropower generation in the simulated period in the "Hydropower", "Irrigation/supply" and "Navigation" scenarios is around $2950 \mathrm{MW}$ (25,840 GWh/year). In the scenario aiming at supplying the environmental minimum flow the annual average generation is around $3000 \mathrm{MW}(26,280 \mathrm{GWh} / \mathrm{year})$, while in the "Drought" scenario the average is $2800 \mathrm{MW}(24,528 \mathrm{GWh} /$ year $)$. 


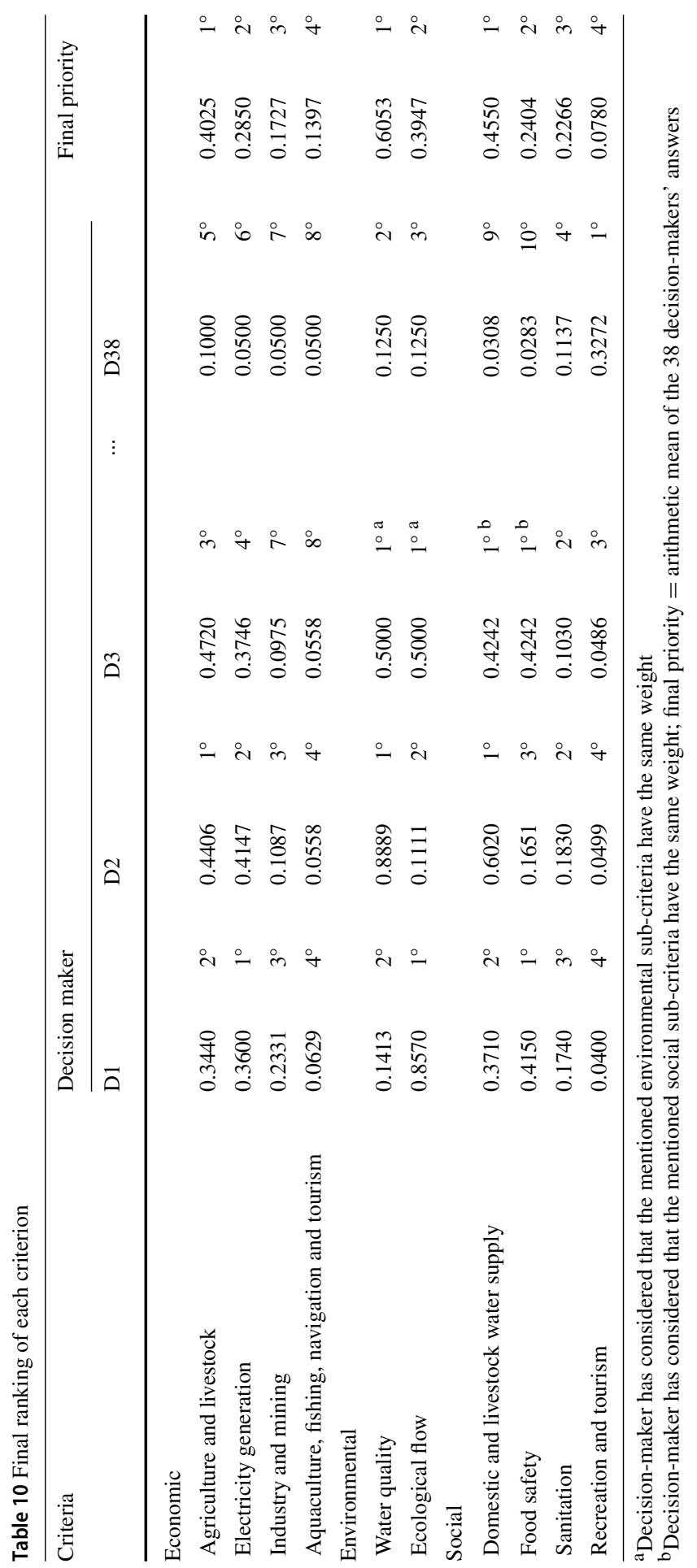




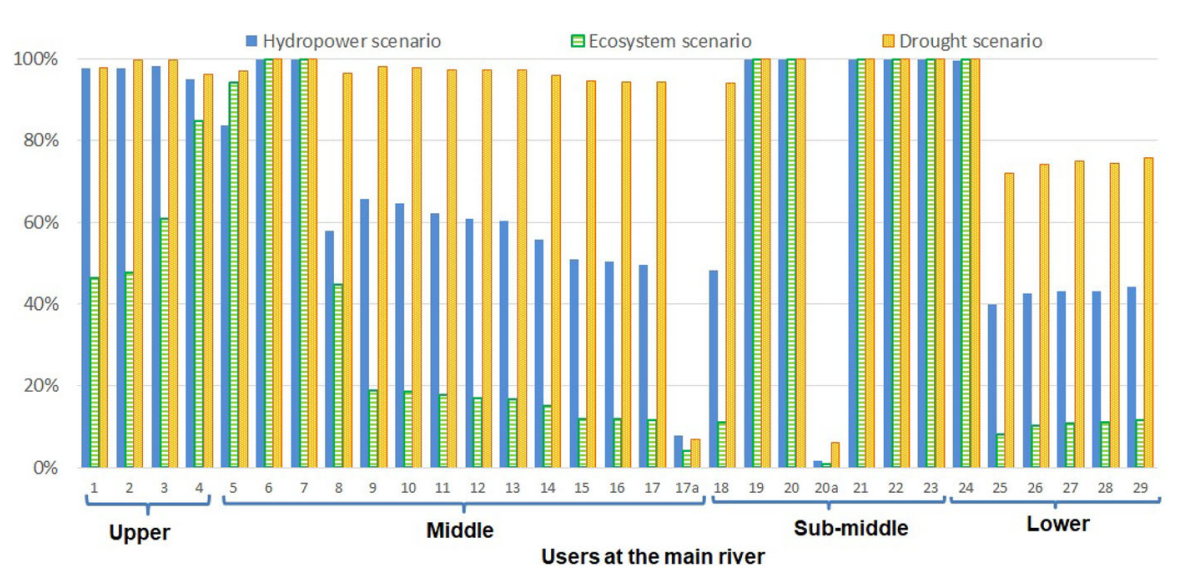

Fig. 8 Percentage of water demand meeting (2021-2050) for 29 major water users that withdraw water from the São Francisco main river from different sectors in the "Hydropower", "Ecosystem" and "Drought" scenarios-Set A

During the year 2016 the observed annual electricity averages were around 2517 MW (20,049 GWh/year) [51]. Low rainfall indices towards the end of 2012 lowered hydropower generation, leading to a significant rise in electricity generation via thermal primary resources [46]. This reinforced the tendency of hydropower generation getting gradually much lower than in the previous decade, making aware of the necessity of a stronger diversification of the electrical matrix in NE and of higher investment in renewable resources.

Water demand for irrigation and domestic supply When analyzing the withdrawals and water availability for the many users in the São Francisco River Basin, the different scenarios assume distinct configurations. Even though the watershed management plan [17] highlights that $76 \%$ of the granted flow in the basin is for agriculture and that there was a 136\% rise in irrigated areas between 2004 and 2013 (pointing to a rising tendency in the future demand) the flow demand considered in the model in the simulated period (2021-2050) was kept constant and equal to the current one. Therefore, the real situation may even be more critical.

In the "Drought" scenario the low discharge in Três Marias Reservoir is kept constant both in rainy and dry periods (Fig. 8). That is, in rainy periods the reservoir accumulates more water and thus in drier periods it can maintain a regular flow of $200 \mathrm{~m}^{3} / \mathrm{s}$. The compliance to legal restrictions for water withdrawal by users in this scenario was relaxed to allow the use of water even with low levels and low discharges of reservoirs. Figure 8 shows that along almost the entire river basin agriculture, domestic supply, fishing and industry sectors are met in more than $90 \%$ of cases, and downstream Xingó (users 27-29) the percentage drops to 70\%. The "Hydropower" scenario presents low values for downstream Xingó users (around 40\%), confirming conflicts mentioned by Silva [68] and CBHSF [17].

The "Irrigation/supply" scenario (Fig. 9) presents percentages above $60 \%$ along the entire basin. In the "Ecosystem" and "Navigation" scenarios, the sections downstream the Sobradinho Reservoir (users 8-19) and Xingó present results below $20 \%$ 


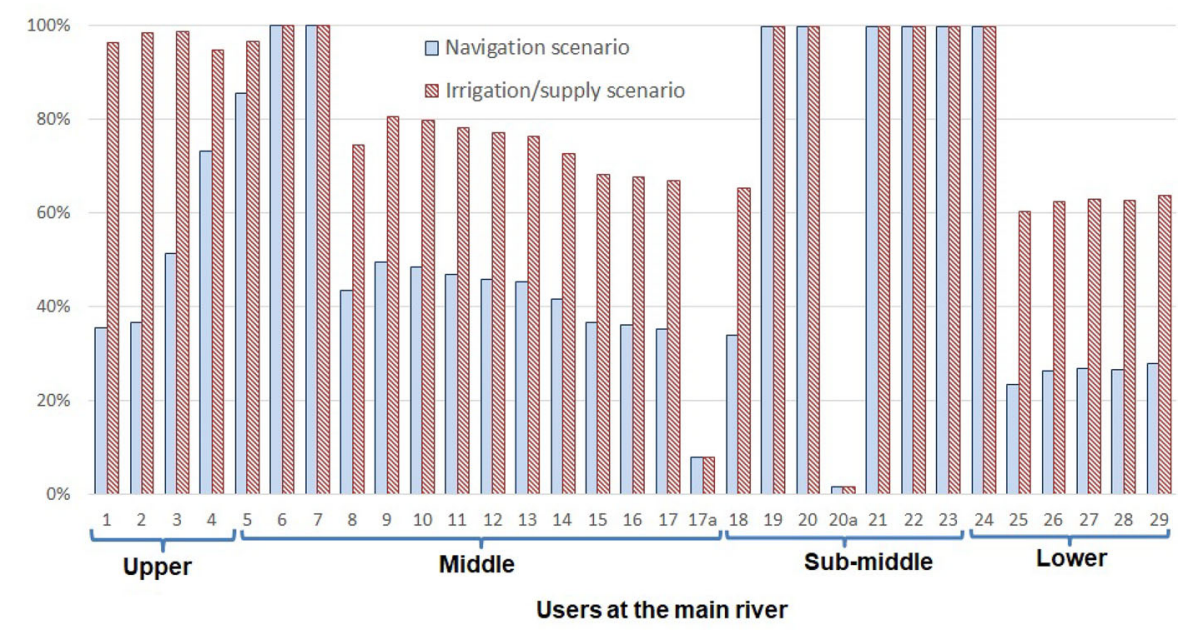

Fig. 9 Percentage of meeting the water demand (2021-2050) for 29 major water users that withdraw water from the São Francisco main river from different sectors in the "Navigation" and "Irrigation/supply" scenarios-Set A

in meeting the demand, causing major damages or losses-mostly in irrigated agriculture. Silva [68] and CBHSF [17] highlight conflicts in this region in the agricultural sector, domestic water supply and fishing activities due to alterations in the river levels downstream Xingó. Among the 29 users distributed along the São Francisco River, the sub-groups 17a and 20a would not receive even $10 \%$ of their flow demand in any of the simulated scenarios. These sub-groups are ramifications of groups 17 and 20 which are, respectively, the north and east water diversion axes of the São Francisco River into other watersheds northwards. According to ANA [8] the projected demand for both axes, at any time, to meet only domestic and animal consumption (demand of groups 17 and 20) would be $26.4 \mathrm{~m}^{3} / \mathrm{s}$ (minimum flow). The withdrawal of a daily maximum flow of $114.30 \mathrm{~m}^{3} / \mathrm{s}$ (sub-groups $17 \mathrm{a}$ and 20a) would be allowed for meeting demand of other uses, depending on the Sobradinho Reservoir level. Therefore, domestic and livestock supply (group 17) along the northern axis would have a better guarantee of supply in the "extreme" scenario (93\%). In the eastern axis (group 20) all scenarios ensure a supplying percentage above $95 \%$. However, supplying other users (group 17a and 20a) in both axes and in all simulated scenarios remains between 2 and $6 \%$.

Navigation and ecosystem demand To analyze the minimal water levels (Table 5) for navigability and the ecosystem of the São Francisco River in all scenarios during the simulated period (2021-2050), four representative hydrological stations-one in each physiographic region of São Francisco Basin-were taken as references: São Romão (Upper), Manga (Middle), Juazeiro (Sub-Middle) and Propriá (Lower). For each hydrological station the number of months in which the minimal flow was reached or surpassed was quantified (Table 11). São Romão and Manga are located between control points I and $\mathrm{V}$ (minimal flow of $500 \mathrm{~m}^{3} / \mathrm{s}$ for navigation and of $420 \mathrm{~m}^{3} / \mathrm{s}$ for ecosystem) and Juazeiro and Propriá downstream of control point VI (minimal flow 
Table 11 Months in which Qmin $\left(\mathrm{m}^{3} / \mathrm{s}\right)$ for navigation and ecosystem are reached or surpassed (max. 360 months) according to the simulated scenarios

Navi navigation, Eco ecosystem

\begin{tabular}{|c|c|c|c|c|c|c|c|c|}
\hline \multirow[t]{2}{*}{ Scenarios } & \multicolumn{2}{|c|}{ São Romão } & \multicolumn{2}{|c|}{ Manga } & \multicolumn{2}{|c|}{ Juazeiro } & \multicolumn{2}{|c|}{ Propriá } \\
\hline & Navi & Eco & Navi & Eco & Navi & Eco & Navi & Eco \\
\hline Hydropower & 260 & 301 & 261 & 300 & 173 & 62 & 93 & 62 \\
\hline Irrigation/supply & 260 & 301 & 261 & 300 & 173 & 62 & 93 & 62 \\
\hline Drought & 305 & 332 & 302 & 333 & 117 & 31 & 43 & 42 \\
\hline Navigation & 262 & 303 & 267 & 309 & 173 & 62 & 95 & 64 \\
\hline Ecosystem & 262 & 303 & 264 & 303 & 174 & 62 & 99 & 66 \\
\hline
\end{tabular}

of $1300 \mathrm{~m}^{3} / \mathrm{s}$ for navigation and the environmental hydrograph from Project AIHA for "Ecosystem"; see Fig. 1 and Table 5).

Even in the "Navigation" scenario, in which the minimum flows are increased to support navigability, no significant differences can be observed in relation to the other scenarios, aside from the "Drought" scenario. For example, at the São Romão station, after all user demands are met ("Irrigation/supply" scenario), 260 months out of a total of 360 would still meet the navigation demand, whilst in the "Navigation" scenario there would be an increase in meeting the needs of only 2 months ( 262 months). In the "Drought" scenario the São Romão and Manga stations would provide a better supply index, while Juazeiro and Propriá stations would provide a worse index. Ramina [57] points out that the section downstream of Sobradinho faces difficulties in staying navigable. Therefore the "Drought" scenario would be the most problematic as it presents a lower index of meeting demands in the Sub-Middle and Lower São Francisco. The needs for ecosystems present similar tendencies as navigation, with similar values among scenarios and hydrological stations (Table 11).

\subsubsection{Set B: under a moderate climate change projection}

Hydropower generation The Set B presents little differences among the scenarios (Appendix 4), as it is a scenario with abundance of water. The global climatological model HadGEM is a model which presents much more humid results in the Upper São Francisco and drier results in the Lower São Francisco. Overall, this prospect is more optimistic than Set A. The monthly averages for hydropower generation in the main São Francisco reservoirs in the simulated scenarios vary between 5080 to $5140 \mathrm{MW}$ (44,026 to $45,500 \mathrm{GWh} /$ year), reproducing a situation similar to the period before 2013, that is, before the recent years of drought which have struck the region.

Water demand for domestic supply and irrigation The Set B simulations (Fig. 10) present "better" results than those of Set A (Fig. 9) in regard to meeting the water demands. The "Ecosystem" scenario downstream of Sobradinho and Xingó presents a prospect three times more positive than in Set A, that is, the monthly average percentages of reaching the desired water levels are threefold. The "Hydropower" scenario achieves percentages above $80 \%$ along the entire river basin, except for the demand of the north and east axes of the São Francisco River water diversion to meet group users 17a and 20a. Similarly, the "Navigation" scenario matches the demand downstream of 


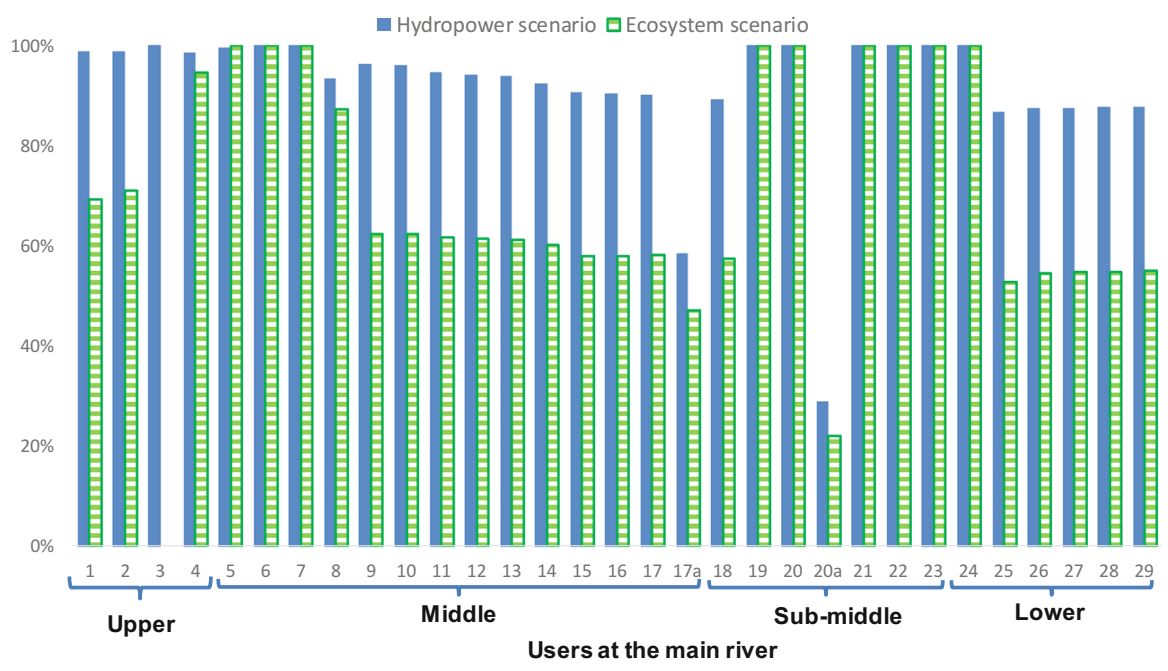

Fig. 10 "Hydropower" and "Ecosystem" scenarios: percentages of meeting the water level demands (2021-2050)—Set B

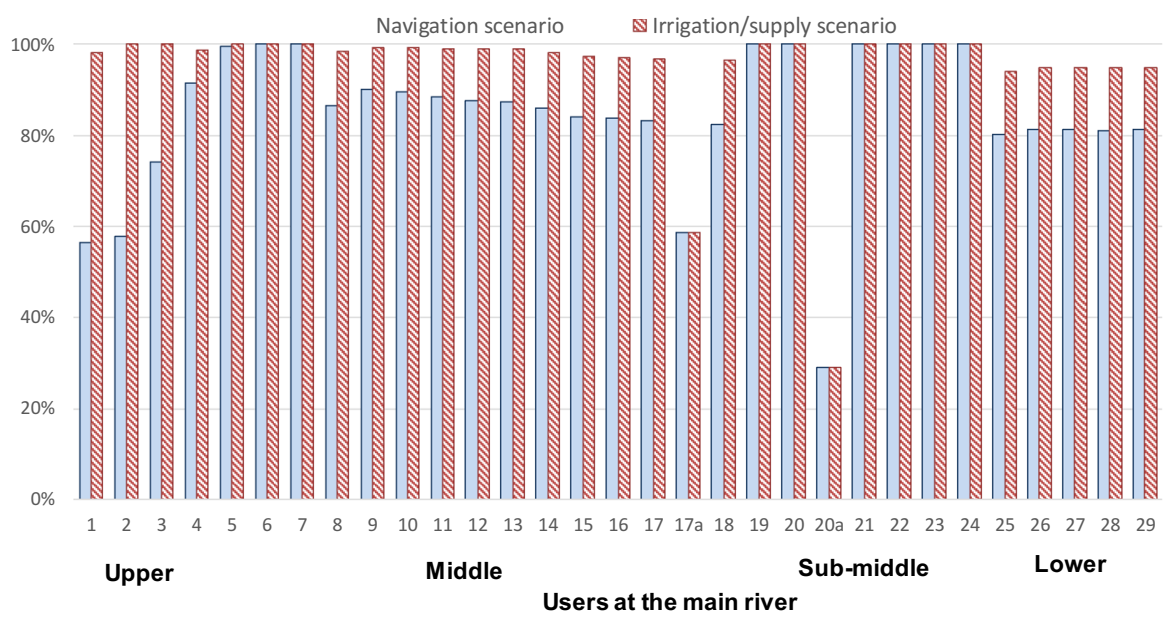

Fig. 11 "Navigation" and "Irrigation/supply" scenarios: meeting their water demands according to monthly average percentages (2021-2050) — Set B

Sobradinho and triples it downstream of Xingó (Fig. 11). The "Irrigation/supply" scenario presents improved results when compared to Set A; it meets water demands on average above $90 \%$ along the entire river. In the "Ecosystem" scenario the percentages also present results that are much more positive than in Set A, mainly downstream of Xingó, with percentages around 50\%.

Navigation and ecosystem demand The same methodology applied in Set A was used to analyze the number of months in which the discharges met the demands of 
Table 12 Months in which Qmin $\left(\mathrm{m}^{3} / \mathrm{s}\right)$ for navigation and ecosystem are reached or surpassed (max. 360 months)

Navi navigation, Eco ecosystem

\begin{tabular}{|c|c|c|c|c|c|c|c|c|}
\hline \multirow[t]{2}{*}{ Scenarios } & \multicolumn{2}{|c|}{ São Romão } & \multicolumn{2}{|c|}{ Manga } & \multicolumn{2}{|c|}{ Juazeiro } & \multicolumn{2}{|c|}{ Propria } \\
\hline & Navi & Eco & Navi & Eco & Navi & Eco & Navi & Eco \\
\hline Hydropower & 321 & 335 & 328 & 340 & 323 & 229 & 294 & 220 \\
\hline Irrigation/supply & 321 & 335 & 328 & 340 & 323 & 229 & 294 & 220 \\
\hline Navigation & 322 & 336 & 330 & 342 & 324 & 230 & 294 & 221 \\
\hline Ecosystem & 322 & 336 & 330 & 340 & 324 & 230 & 298 & 221 \\
\hline
\end{tabular}

navigation and ecosystem in Set $\mathrm{B}$. The results of the scenarios were similar for both navigation and ecosystem purposes (Table 12).

\section{Discussion, conclusion and recommendations}

\subsection{Hydropower's role in the electricity mix under climate change}

Comparing the results presented in this paper for hydropower generation between 2021 and 2050 and the studies of supply and demand expansion of the National Energy Plan 2030 [46], a reconfiguration in the NE electrical matrix in the near future becomes necessary. The National Energy Plan 2030, in fact, does not decisively address the interference of climate change on hydropower generation and the increasing water demand of other water users nor includes ecological flow requirements. Besides, for the study of the expansion of future offers, it endorses economic criteria that give priority to sources which minimize operation and investment costs.

The water supply to users in the river basin shows a possible rise in conflicts mainly for the agriculture sector and for domestic supply in the simulated "Ecosystem" and "Navigation" scenarios in Set A (the driest projections). Both scenarios propose more restrictions on water withdrawals from the river, and downstream of Sobradinho and Xingó Reservoirs present the lowest percentages in meeting the water demands, compared to the other scenarios. In addition, these scenarios do not present significant gains in the supply index for navigation activities, ecosystem health or hydropower generation, and behave similarly to other scenarios. These scenarios contradict the results of the interviews performed through the IPC method, which highlight the important role of agricultural activities and domestic water supply for the economic and socio-environmental development of the region. Between the "Hydropower" and "Irrigation/supply" scenarios, the latter shows more regularity in meeting the demands of the water-consuming users, satisfying at least $60 \%$ of demand along the river, including the most critical point downstream of Xingó.

The needs for navigation activities and ecosystem have both similar results in all the scenarios and do not present large gains, also for the "Navigation" and "Ecosystem" scenarios which prioritize these sectors. The "Drought" scenario would meet around $90 \%$ of the users' demand along the river and $70 \%$ downstream of Xingó. This would be the scenario with the lowest generation of hydropower and it presents better results for navigability and ecosystem supply in the Upper and Middle São Francisco and a 
lower supply in the Sub-Middle and Lower São Francisco. Despite the fact that this scenario presents more positive results regarding the needs of the water-consuming users, it considers adaptations to allow users to withdraw water from the river even with low levels of, and discharge from reservoirs. Therefore, the index of supply in this scenario could not be compared to the others. In conclusion, the "Drought" scenario simulation indicates that it would be possible to adapt the system (e.g., management of reservoirs, legal restrictions of grants and demands) to extreme drought conditions.

In general terms, the results of the "Irrigation/supply" scenario present river flows very similar to those experienced today (Table 5). The scenario adopts values of minimal flows already adapted to the current hydrological conditions and guarantees the supply of at least $60 \%$ of the water demand in the most critical section, i.e. downstream of Xingó (Fig. 10). In addition, it prioritizes the need of activities designated by interviewees as the most important for the economic and socio-environmental development of the basin. The "Hydropower" scenario output in terms of meeting the other water users' demands was the worst. The scenario "Drought", for instance, performed much better in this sense. On the other hand, the scenarios showed little differentiation regarding the potential hydropower generation. Even the scenario prioritizing it ("Hydropower"), was not significantly different from the others' projected capacity.

Within both sets, except for the "Drought" scenario in Set A, the results for hydropower generation are very similar. This is explained by the reservoir management targeting at a certain yield for hydropower generation. In case the inflows and reservoir volumes are somewhat higher or lower, e.g. due to changed inflow caused by different minimum flow settings upstream, the reservoirs are discharging somewhat higher, or lower, respectively, volumes to deliver the targeted electricity. This is only seen in changed reservoir volumes for the different scenarios within each set. The differences between the scenarios therefore are much more clearly visible in the results for water users, where different minimum flows are applied. Also differences for reaching or surpassing minimum flows (Table 11), except for the "Drought" scenario in Set A, are not strongly diverging. In the simulations, water withdrawing is allowed, if the assigned minimum flow condition in the river stretch is ensured, i.e. only water volumes above the minimum flow can be withdrawn. Therefore, only in case the river flow is close to the set minimum flow the latter will affect the quantities of water withdrawn.

Analyzing the electricity balance of the NE in more detail, the installed capacity of hydropower plants is currently approximately 11,975 MW [51]. According to the physical guarantee ${ }^{11}$ factor, calculated based on ONS data [49], the hydropower generation ensured in 2030 should be approximately $6700 \mathrm{MW}(58,700 \mathrm{GWh} / \mathrm{year})$. The National Energy Plan 2030 considers an increase of around 5\% in the offer until 2030. However, when considering the "Irrigation/supply" scenario for the planning of the future electricity matrix in the NE, a reduction of approximately $58 \%$ in water supply is noted in scenarios of Set A, compared to what provided in the plan, and $27 \%$ for Set B scenarios. The mentioned plan also anticipates an increase of $35 \%$ for other

\footnotetext{
11 Physical guarantee-corresponds to the maximum energy which can be provided according to a given criterion of security. The factors of physical guarantee were calculated based on the installed capacity and insured energy supplied by the ANEEL information database of generation [9].
} 
renewable sources, $85 \%$ for biomass and $90 \%$ for fossil fuels [45]. The percentages presented in the National Energy Plan 2030 are very modest considering the high potential for wind and solar generation that the region presents, the 10-years Energy Plan 2024 which already anticipates an increase of approximately $10 \%$ per year for wind power [46], and the positive provisions for encouraging photovoltaic projects in Brazil, according to EPE and the Brazilian Association of Photovoltaic Energy.

In 2016 the annual average electricity demand in the NE region was approximately 12,000 MW [51]. Considering the economic and energy assumptions as well as the macroeconomic and demographic scenarios from 2013 to 2050, demand is expected to rise of $3.1 \%$ per year at the national level [47]. Therefore, according to Table 10, the "Irrigation/supply" scenario of both simulated Sets (A and B) shows a deficit in the balance of electricity supply and demand in 2030, which is also the current situation in the NE. Thus the region would still need to import electrical energy from other sub-systems in Brazil.

Considering the different electricity balances presented in Table 13 for 2030, massive investments are recommended-based on the expansion potential of the region presented in the National Energy Plan 2030 and in the Decennial Energy Plan 2024-in other renewable sources, biomass and fossil fuels to fulfill the expansion plan of the offer until 2050. The simulated sets and scenarios of low water availability show a strong tendency towards reduction of hydropower generation offer in the river basin. It alerts on the necessity of adaptations to the effects of climate change. Moreover, the $\mathrm{NE}$ is more vulnerable to blackouts, as it is very dependent on other regions through interconnections by transmission lines. Reduction of hydropower is recommended in the basin over the years, thereby reducing its high dependency on water resources along with conflicts due to the management of reservoirs primarily for the electrical sector. Another important point is to invest in increasing the efficiency of irrigated agriculture, avoiding waste in water use and electricity. To support electricity planning of the region until 2050, the necessity of a multi-criteria analysis is confirmed by the multi-disciplinary nature of the decisions. The "Irrigation/supply" scenario of Sets A and B is recommended to guide the formulation of alternatives based on the predicted hydropower generation, which involve different possibilities to increase the offer of wind, solar, biomass and fossil fuel sources analyzed according to criteria and sub-criteria which involve the indicators highlighted by the actors and stakeholders in Table 8 .

\subsection{MCDA in the decision-making process}

A major critique of MCDA applications is the often too vague or insufficient elaboration of its objectives [18]. Our study provides an example of how this can be remedied through a careful and well-documented approach. In total, in our analysis, there are four criteria: technical, economic, social and environmental, and 28 sub-criteria. Among these 28 sub-criteria, 12 were highlighted as particularly relevant through surveys. It was noted that the sub-criteria mentioned as relevant by interviewees have also been frequently used and quoted in the literature (see Appendix 1). 


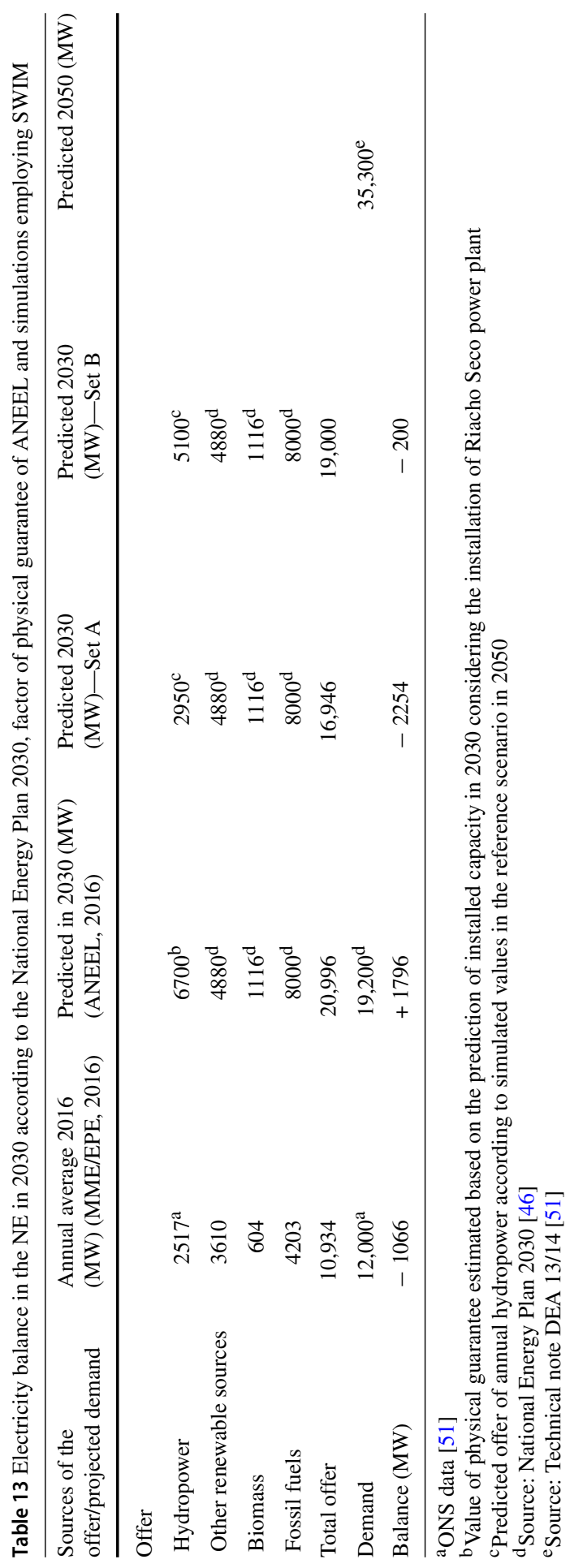


This study established entry points for the MCDA evaluation phase (see Fig. 3). The SSM methodology for problem structuring proposed by Coelho et al. [19] and Neves et al. [48] includes the creation of a conceptual model presenting the necessary activities with the purpose of achieving the expected goals, i.e. it allows the comparison of the model with real data so that the differences which may arise become changing points and solutions, and also the definition of actions to improve the problem framework. With regard to the problem structuring phase, the SWIM model was used for hydro-ecological modeling in order to predict different scenarios considering several water withdrawal priorities in the São Francisco River. The methodology used for the selection of criteria was adapted from Cloquell-Ballester et al. [16] as well as interviews using multi-criteria Borda's method [3, 49] and Incomplete Pairwise Comparison [28]. These stages will be included in the upcoming process of MCDA modeling (evaluation phase), which will be resolved comparing the scenarios' scores, selection of the MCDA method, normalization, weighting and then concluded with the trade-off analysis in order to rank the suitable alternatives to reduce conflicts and identify options for sustainable electricity sources.

MCDA is often considered as a highly subjective analysis; therefore, this paper focusses on a detailed description and justification of the adopted methods in order to keep up a high degree of transparency of its application. Nevertheless, it is noteworthy to state the limitations of the chosen set of methods. Overall, the participation of stakeholders was limited to few stages in the analysis, which might have caused a lack of involvement of the affected communities and their interests in this specific decisionmaking process. The process of interviewees' selection followed an opportunistic, rather than a transparent and systematic approach. Under these conditions, the sample is unlikely to be representative. It would be very interesting to repeat and compare with affected stakeholders who are professionally not linked at all to the energy sector. Overall, more frequent visits to the case study region and more effective participation of water users and stakeholders from the São Francisco River Basin would have been desirable, even if this would have required more resources than those provided for our study. Moreover, the data collection could have been done through workshops and face-to-face meetings, so that the cultural, social, economic and political dimensions, as well as the interviewees' relationships with their environment, could have been perceived in a clearer and more collaborative way. The conceptual scheme (Fig. 3) elaborated in this phase would have been even more efficient if workshops were carried out for this specific purpose.

The scenarios could not reflect basic pre-existing conditions of the basin such as priority for domestic and animal water supply in times of scarcity. The consequence is the lack of accuracy of the model in distinguishing the real percentage in meeting water demand for each sector within the "Irrigation/supply" scenario (agricultural, domestic and animal supply). The model mainly considers the priority in supplying water to the users located upstream of the river. Therefore, adding a priority system parameter in the scenario simulation could contribute to the discussion about the reformulation of the permit granting system in the basin.

The present paper offers systematic means to the basin committees and the governments to address the climate change concerns in the water basin plans and the electrical planning. Such concerns have not been properly debated and considered in these plans 
yet. The scenarios simulated the hydropower generation and the water users' supply. These can be used, for example, to analyze water allocation for various users in the basin to reduce the conflicts of use. In addition, they can be used to estimate, considering the climatological aspect, the contribution of hydropower, in addition to future sources of solar, wind and thermal in planning the new configurations of the future regional composition of electricity sources.

For future applications of the MCDA, it is recommended to use a detailed mapping for the selection of stakeholders, contemplating a systemic process to collect and analyze information on the interests, objectives, and preferences of the stakeholders in a transdisciplinary approach. Also, it is suggested to map the risks, needs and quantify the degrees of power and influence of each stakeholder in the basin. As for the problem structuring, the Constellation Analysis is another promising method, which was for instance used to translate the challenges of the basin committees in the governance of the water resources in the São Francisco River Basin [66]. Finally, for the scenarios' design, it is recommended the development of scenarios that would disregard the minimum limit of the operational discharge from the reservoirs for hydropower generation, with the objective of analyzing the hydropower generation reduction in the local energy matrix and its substitution by alternative sources. In this way, more tangible differences could be foreseen in the results for hydropower generation.

\subsection{Relevance of the study}

The electricity sector in the São Francisco River Basin faces a crisis. The main issues are the high dependence on the hydropower generation, the increasing conflicts over the water use and the water scarcity due to the hydrological drought and prevailing management practices. The simulated scenarios showed a strong tendency to reduce the supply for hydropower generation in the coming years. Therefore, it is necessary to restructure the current electricity production framework incorporating climate change, the socio-environmental concerns, and the tools that aid decision-making into the electric supply expansion plans. A well-managed MCDA can facilitate this complex task. Our study is exploratory insofar we have developed the prerequisites for a complete MCDA and are aware of shortcomings, since a comprehensive MCDA for the complex situation under study would involve a much larger group of facilitators and stakeholders. The prerequisites presented here (the structuring phase) will be further employed in the evaluation phase of the MCDA. The final goal is a more resilient, reliable, and environmentally and socially responsible electricity production sector.

Acknowledgements We are grateful to the funding organization of the INNOVATE Project (BMBF, No. 01LL0904A and 01LL0904D), a personal grant provided by CNPq (248569/2013-9), and CHESF for temporary release from work for the lead author. We are grateful to the stakeholders who took time to respond to our questionnaires.

Open Access This article is distributed under the terms of the Creative Commons Attribution 4.0 International License (http://creativecommons.org/licenses/by/4.0/), which permits unrestricted use, distribution, and reproduction in any medium, provided you give appropriate credit to the original author(s) and the source, provide a link to the Creative Commons license, and indicate if changes were made. 


\section{Criteria/sub-criteria}

Technical

S1 Energy efficiency

S2 Availability factor

S3 Production capacity

S4 Technological maturity

S5 Reliability

S6 Dependence on external sources

S7 Energy guaranteed

Economic

S8 Investment cost

S9 Operation and maintenance cost (O\&M)

S10 Fuel cost

S11 Payback

S12 Electricity cost

S13 Conflicts between electricity sector and navigation

S14 Conflicts between electricity sector and other users

S15 Equivalent annual cost

Environmental

$\begin{array}{ll}\text { S16 } & \text { Impacts on the ecosystem } \\ \text { S17 } & \mathrm{CO}_{2} \text { emission } \\ \text { S18 } & \text { NOx emission } \\ \text { S19 } & \text { CO emission } \\ \text { S20 } & \mathrm{SO}_{2} \text { emission } \\ \text { S21 } & \text { Land use } \\ \text { S22 } & \text { Noise emission } \\ \text { S23 } & \text { Solid and liquid wastes } \\ \text { Social } & \\ \text { S24 } & \text { Public acceptance } \\ \text { S25 } & \text { Job creation } \\ \text { S26 } & \text { Local income } \\ \text { S27 } & \text { Fatalities } \\ \text { S28 } & \text { Visual impacts }\end{array}$

References

$[2,5,10,13,24,32,52,72,75]$

$[10,22]$

$[10,21,72]$

$[5,11,14,17,21,24,32,71,72,75]$

$[5,10,11,21,24,32,71,75,78]$

$[17,47,59]$

$[7,50]$

$[2,10,20-22,23,25,27,32,39,53,54,72,75]$ $[5,9,10,14,20,21,25,32,34,53,72,75]$

$[10,32,72,75]$

$[21,26,32,75]$

$[2,5,32,39,51]$

Criterion developed by the author

Criterion developed by the author

$[32,75]$

$[5,21]$

$[2,5,11,17,22,32,39,59,75,78]$

$[5,17,22,32,39,71,75,78]$

$[5,11,22,32,75,78]$

$[17,22,32,53,71,75,78]$

$[2,5,11,17,25,32,59,75,78]$

$[25,32,59,75]$

$[17,32,72,78]$

$[5,17,21,32,71,72,75,78]$

[5, 13, 17, 25, 26, 32, 39, 73-75]

$[32,59]$

$[9,21,24,32,75]$

$[10,25]$ 


\section{Appendices}

\section{Appendix 1: Criteria and sub-criteria selected according to Fig. 5}

\section{Appendix 2: Structuring a decision-making hierarchical process for water allocation}

Questionnaire A: Prioritization of criteria for efficient water allocation in the São Francisco basin

1a: How many times is the ECONOMIC approach of water more or less important than the SOCIAL and ENVIRONMENTAL approach for a more adequate water allocation in the São Francisco river basin?

2a: How many times is the SOCIAL approach of water more or less important than the ENVIRONMENTAL for a more adequate water allocation in the São Francisco river basin?

Questionnaire B: Prioritization of sub-criteria for efficient water allocation in the São Francisco River basin

1b: How many times is WATER DOMESTIC SUPPLY more or less important than WATER FOR SANITATION, FOOD SECURITY, RECREATION AND TOURISTIC ACTIVITIES under the SOCIAL viewpoint?

2b: How many times is WATER FOR SANITATION more or less important than FOOD SECURITY, RECREATION AND TOURISTIC ACTIVITIES under the SOCIAL viewpoint?

3b: How many times is FOOD SECURITY more or less important than RECREATION AND TOURISTIC ACTIVITIES under the SOCIAL viewpoint?

4b: How many times is AGRICULTURE AND LIVESTOCK DEVELOPMENT more or less important than POWER GENERATION, INDUSTRY AND MINING and FISH-FARMING AND FISHING under the ECONOMIC viewpoint?

5b: How many times is POWER GENERATION more or less important than INDUSTRY AND MINING and FISH-FARMING AND FISHING under the ECONOMIC viewpoint?

6b: How many times is INDUSTRY AND MINING more or less important than FISH-FARMING AND FISHING under the ECONOMIC viewpoint?

7b: How many times is WATER QUALITY more or less important than ECOLOGICAL FLOW, under the ENVIRONMENTAL viewpoint? 
Appendix 3: Simulated hydropower generation in the São Francisco River Basin (2021-2050) according to five scenarios-Set A (severe climate change projection)

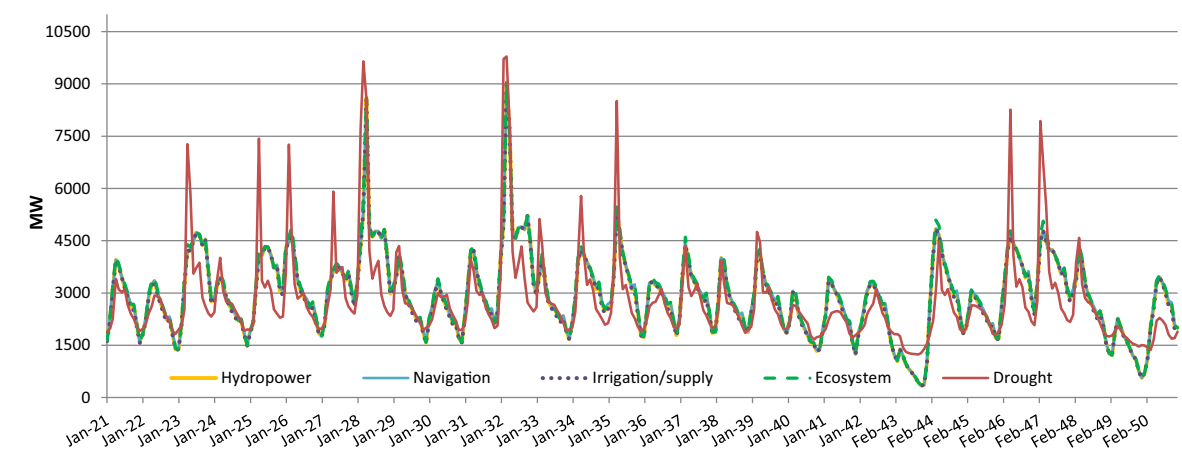

Appendix 4: Hydropower generation in the São Francisco River Basin (2021-2050) according to four scenarios-Set $B$ (moderate climate change projection)

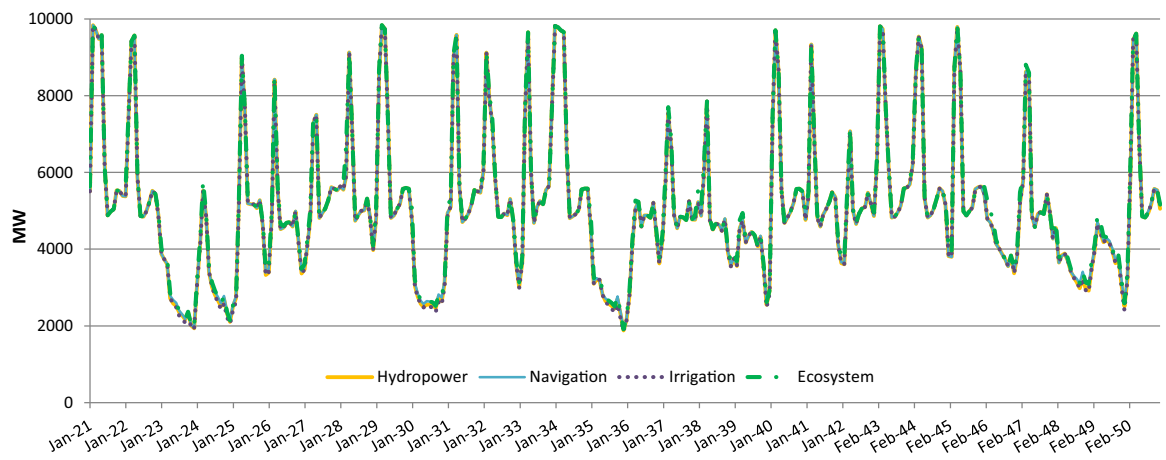

\section{References}

1. Abulfotuh, F.: Energy efficiency and renewable technologies: the way to sustainable energy future. Desalination 209, 275-282 (2007)

2. Afgan, N., Carvalho, M.: Multi-criteria assessment of new and renewable energy power plants. Energy 27, 739-755 (2002)

3. Almeida, A.T., Morais, D.C., Costa, A.P.C.S., Alencar, L.H., Daher, S.F.D.: Decisão em Grupo e Negociação. Atlas, São Paulo (2012)

4. Altuzarra, A., Moreno-Jimenez, J.M., Salvador, M.: A Bayesian prioritization procedure for AHPgroup decision making. Eur. J. Oper. Res. 182, 367-382 (2007)

5. Amer, M., Daim, T.U.: Selection of renewable energy technologies for a developing country: a case of Pakistan. Energy Sustain. Dev. 15, 420-4432 (2011)

6. Amarante, O., Zack, M., Sá, A.: Atlas do Potencial Eólico Brasileiro. Camargo Shubert Engenharia Eólica, TrueWind Solution, CEPEL. http://www.cresesb.cepel.br/index.php?section=publicacoes\&ta sk=livro\&cid=1. Accessed 03 Feb 2017 
7. ANA: Agência Nacional de Águas. http://www2.ana.gov.br/Paginas/servicos/saladesituacao/v2/saofra ncisco.aspx. Accessed 15 Jan 2017

8. ANA: Agência Nacional de Águas. Resolução No. 74272017. http://arquivos.ana.gov.br/resolucoes/ 2017/224-2017.pdf. Accessed 06 July 2017

9. ANEEL: Agência Nacional de Energia Elétrica. Banco de Informação da Geração. http://aneel.gov. br. Accessed 15 March 2018

10. Aras, H., Erdogmus, S., Koç, E.: Multi-criteria selection for a wind observation station location using analytic hierarchy process. Renew. Energy 29, 1383-1392 (2004)

11. Athanasios, I., Chatzimouratidis, A.I., Pilavachi, P.A.: Technological, economic and sustainability evaluation of power plants using the Analytic Hierarchy Process. Energy Policy 37, 778-787 (2009)

12. Beccali, M., Cellura, M., Mistretta, M.: Decision-making in energy planning. Application of the ELECTRE method at regional level for the diffusion of renewable energy technology. Renew. Energy 28, 2063-2087 (2003)

13. Bilgen, S., Keles, S., Kaygusuz, A., Sari, A., Kaygusuz, K.: Global warming and renewable energy sources for sustainable development: a case study in Turkey. Renew. Sustain. Energy Rev. 12, 372-396 (2008)

14. Blanco, G., Amarilla, G., Martinez, C., Llamosas, V., Oxilia, V.: Energy transitions and emerging economies: a multi-criteria analysis of policy options for hydropower surplus utilization in Paraguay. Energy Policy 108, 312-321 (2017)

15. Cannemi, M., García-Melón, M., Aragonés-Beltrán, P.: Modeling decision making as a support tool for policy making on renewable energy development. Energy Policy 67, 127-137 (2014)

16. Cavallaro, F.: Multi-criteria decision aid to assess concentrated solar thermal technologies. Renew. Energy 34, 1678-1685 (2009)

17. CBHSF: Plano de Recursos Hídricos da Bacia Hidrográfica do São Francisco: resumo executivo do plano de recursos hídricos. http://cbhsaofrancisco.org.br/planoderecursoshidricos/relatorios/. Accessed 01 Dec 2016

18. Cloquell-Ballester, V.A., Monterde-Diaz, R., Santamarina-Siurana, M.C.: Indicators validation for the improvement of environmental and social impact quantitative assessment. Environ. Impact Assess. 26, 79-105 (2006)

19. Coelho, D., Antunes, C.H., Martins A.G.: Using SSM for structuring an MCDA model for sustainable urban energy planning. In: 5th International Vilnius Conference, pp. 102-107 (2009)

20. Creative Decision Foundation: Super Decision Software for decision making. http://superdecisions. com/. Accessed 15 Nov 2016

21. Cristóbal, J.R.S.: Multi-criteria decision-making in the selection of a renewable energy project in Spain: the Vikor method. Renew. Energy 36, 498-502 (2010)

22. Demirtas, O.: Evaluating the best renewable energy technology for sustainable energy planning. Int. J. Energy Econ. Policy 3, 23-33 (2013)

23. Diakoulaki, D., Karangelis, F.: Multi-criteria decision analysis and cost-benefit analysis of alternative scenarios for the power generation sector in Greece. Renew. Sustain. Energy Rev. 11, 716-727 (2007)

24. Garjulli, R.: Oficinas Usos Múltiplos das Águas do Rio São Francisco. http://cbhsaofrancisco.org.b r/?wpfb_dl=993. Accessed 17 Dec 2016

25. Garni, H., Kassem, A., Awasthi, A., Komljenovic, D., Al-Haddad, K.: A multicriteria decision making approach for evaluating renewable power generation sources in Saudi Arabia. Sustain. Energy Technol. Assess. 16, 137-150 (2016)

26. Georgopoulou, E., Lalas, D., Papagiannakis, L.: A Multicriteria Decision Aid approach for energy planning problems: the case of renewable energy option. Eur. J. Oper. Res. 103, 38-54 (1997)

27. Haralambopoulos, D.A., Polatidis, H.: Renewable energy projects: structuring a multi-criteria group decision-making framework. Renew. Energy 28, 961-973 (2003)

28. Harker, P.T.: Incomplete pairwise comparisons in the analytic hierarchy process. Math. Model. 9(11), 837-848 (1987)

29. Hattermann, F.F., Weiland, M., Huang, S., Krysanova, V., Kundzewicz, Z.W.: Model-supported impact assessment for the water sector in Central Germany under climate change — a case study. Water Resour. Manag. 25(13), 3113-3134 (2011)

30. Hempel, S., Frieler, K., Warzawski, L., Schewe, J., Piontek, F.A.: Trend-preserving bias correction-the ISI-MIP approach. Earth Syst. Dyn. 4(2), 219-236 (2013)

31. Hofman, K., Li, X.: Canada's energy perspectives and policies for sustainable development. Appl. Energy 09, 407-415 (2009) 
32. Kablan, M.: Decision support for energy conservation promotion: an analytic hierarchy process approach. Energy Policy 32, 1151-1158 (2004)

33. Kahraman, C., Kaya, I., Cebi, S.: A comparative analysis for multiattribute selection among renewable energy alternatives using fuzzy axiomatic design and fuzzy analytic hierarchy process. Energy 34, $1603-1616$ (2009)

34. Kambezidis, H.D., Kasselouri, B., Konidari, P.: Evaluating policy options for increasing the RES-E penetration in Greece. Energy Policy 39, 5388-5398 (2011)

35. Karatayev, M., Hall, S., Kalyuzhnova, Y., Clarke, M.L.: Renewable energy technology uptake in Kazakhstan: policy drivers and barriers in a transitional economy. Renew. Sustain. Energy Rev. 66, 120-136 (2016)

36. Koch, H., Liersch, S., de Azevedo, J.R.G., Silva, A.L.C., Hattermann, F.F.: Assessment of observed and simulated low flow indices for a highly managed River basin. Hydrol. Res. (2018). https://doi. org/10.2166/nh.2018.168. (online available)

37. Koch, H., Silva, A., Azevedo, R., Souza, W., Köppel, J., Souza Júnior, C.B., Hattermann, F.: Integrated hydro- and wind power generation: a game changer towards environmental flow in the Sub-middle and Lower São Francisco River Basin? Reg. Environ. Change 18, 1927-1942 (2018). https://doi.org/ 10.1007/s10113-018-1301-2

38. Krysanova, V., Wechsung, F., Arnold, J., Srinivasan, R., Williams, J.: Soil and Water Integrated Model: User Manual. PIK Report 69. Potsdam Institute for Climate Impact Research, Potsdam (2000)

39. Liu, H., Liang, D.: A review of clean energy innovation and technology transfer in China. Renew. Sustain. Energy 18, 486-498 (2013)

40. Lombardi, P., Sokolnikova, T., Suslov, K., Voropai, N., Styczynski, A.: Isolated power system in Russia: a chance for renewable energies? Renew. Energy 90, 532-541 (2015)

41. Luthra, S., Kumar, S., Garg, D., Haleem, A.: Barriers to renewable/sustainable energy technologies adoption: Indian perspective. Renew. Sustain. Energy Rev. 41, 762-776 (2015)

42. Medeiros, Y., Freitas, I., Stifelman, G., O'Keeffe, J.: Social participation in the environmental flow assessment: the São Francisco river case study. Revista Eletronica de Gestão e Tecnologia Ambientais 1, 122-130 (2013)

43. Michnik, J.: Scenario planning + MCDA procedure for innovation selection problem. Found. Comput. Decis. Sci. 1, 1 (2013). https://doi.org/10.2478/fcds-2013-0010

44. Montenegro, S., Ragab, R.: Impact of possible climate and land use changes from North Eastern Brazil. J. Hydrol. 434-435, 55-68 (2012)

45. MME/EPE: Plano Decenal de Expansão de Energia 2024. http://www.epe.gov.br/PDEE/Forms/ EPEEstudo.aspx. Accessed 23 May 2016

46. MME/EPE: Plano Nacional de Energia 2030. http://www.epe.gov.br/PDEE/Forms/EPEEstudo.aspx. Accessed 15 Feb 2016

47. MME/EPE: Nota Técnica DEA 13/15: demanda de energia 2050. http://www.epe.gov.br/PDEE/ Forms/EPEEstudo.aspx. Accessed 23 May 2017

48. Neves, L.P., Dias, L.C., Antunes, C.H., Martins, A.G.: Structuring an MCDA model using SSM: a case study in energy efficiency. Eur. J. Oper. Res. 199, 834-845 (2009)

49. Nurmi, H.: Assessing Borda's rule and its modifications. In: Emerson, P. (ed.) Designing an allinclusive democracy. Consensual voting procedures for use in parliaments, councils and committees, pp. 109-119. Springer, Berlin (2007)

50. ONS: Inventário das restrições operativas hidráulicas dos aproveitamentos hidrelétricos. Operador Nacional do Sistema Elétrico. http://ons.org.br/. Accessed 25 Sep 2016

51. ONS: Operador Nacional de Energia. http://ons.org.br/. Accessed 03 Apr 2017

52. Østergaard, P.A.: Reviewing optimisation criteria for energy systems analyses of renewable energy integration. Energy 34, 1236-1245 (2009)

53. Ferreira, T.V.B.: Hidrograma ambientais para o Baixo São Francisco: avaliação de impactos sobre a geração hidrelétrica, UFRJ/COPPE, pp. 213-240 (2014)

54. Önüt, S., Tuzkaya, U.R., Saadet, N.: Multiple criteria evaluation of current energy resources for Turkish manufacturing industry. Energy Convers. Manag. 49, 1480-1492 (2008)

55. Forman, E., Peniwati, K.: Aggregating individual judgments and priorities with the analytic hierarchy process. Eur. J. Oper. Res. 108, 165-169 (1998)

56. Ram, C., Montibeller, G., Morton, A.: Extending the use of scenario planning and MCDA for the evaluation of strategic options. J. Oper. Res. Soc. 62(5), 817-829 (2011) 
57. Ramina, H.R.: Concepção de uma estratégia robusta para a gestão dos usos múltiplos das águas na bacia hidrográfica do rio São Francisco. http://arquivos.ana.gov.br/saladesituacao/ReducaoTemporaria /RelatoriosCHESF/2015/ConcepcaoUmaEstrategiaRobustaParaGestaoDosUsosMultiplosDasAgua sBaciaHidrograficaRioSaoFrancisco_AEstrategiaRobusta.pdf. Accessed 13 Dec 2016

58. Resnier, M., Wang, C., Du, P., Chen, J.: The promotion of sustainable development in China through the optimization of a tax/subsidy plan among HFC and power generation CDM projects. Energy Policy 35, 4529-4544 (2007)

59. Riahi, K., Krey, V., Rao, S., Chirkov, V., Fischer, G., Kolp, P., Kindermann, G., Nakicenovic, N., Rafai, P.: RCP-8.5: exploring the consequence of high emission trajectories. Clim. Change (2007). https://doi.org/10.1007/s10584-011-0149-y

60. Ribeiro, F., Ferreira, P., Araújo, M.: Evaluating future scenarios for the power generation sector using a Multi-Criteria Decision Analysis (MCDA) tool: the Portuguese case. Energy 52, 126-136 (2013)

61. Saaty, T.L.: How to make a decision: the analytic hierarchy process. Eur. J. Oper. Res. 48, 9-26 (1990)

62. Saaty, T.L.: Fundamentals of decision making and priority theory with the AHP. RWS Publications, Pittsburgh (1994)

63. Saaty, T.L.: The Analytic Hierarchy Process: Planning, priority setting, resource allocation. RWS Publications, Pittsburgh (1997)

64. Saaty, T.L.: Fundamentals of decision making and priority theory: with the analytic hierarchy process. RWS Publications, Pittsburgh (2006)

65. Saaty, T.L.: Getting priorities from a crowd: combining judgments from people with differing perspectives. Int. J. Anal. Hierarchy Process. 4, 161-162 (2012)

66. Siegmund-Schultze, M., Rodorff, V., Köppel, J., Sobral, M.C.: Paternalism or participatory governance? Efforts and obstacles in implementing the Brazilian water policy in a large watershed. Land Use Policy 48, 120-130 (2015)

67. Siegmund-Schultze, M., Köppel, J., Sobral, M.C.: Unraveling the water and land nexus through interand transdisciplinary research: sustainable land management in a semi-arid watershed in Brazil's Northeast. Reg. Environ. Change 7, 2005-2017 (2018)

68. Silva, F.: Oficinas Usos Múltiplos das Águas do Rio São Francisco. http://cbhsaofrancisco.org.br/wpcontent/uploads/. Accessed 17 Dec 2016

69. Silveira, S., Filho, F., Martins, E., Oliveira, J., Costa, A., Nóbrega, M., Souza, S., Silva, S.: Mudanças Climáticas na bacia do São Francisco: uma análise para precipitação e temperatura. Revista Brasileira de Recursos Hídricos 21, 416-428 (2016)

70. Soytas, U., Sari, R.: Energy consumption and income in G-7 countries. J Policy Model 28, 739-750 (2006)

71. Shen, Y., Chou, C.J., Lin, G.T.: The portfolio of renewable energy sources for achieving the three E policy goals. Energy 36, 2589-2598 (2011)

72. Strantzali, E., Aravossis, K.: Decision making in renewable energy investments: a review. Renew. Sustain. Energy 55, 885-898 (2016)

73. Streimikiene, D., Sliogeriene, J., Turskis, Z.: Multi-criteria analysis of electricity generation technologies in Lithuania. Renew. Energy 85, 148-156 (2016)

74. Talinli, I., Topuz, E., Akbay, M.U.: Comparative analysis for energy production processes (EPPs): sustainable energy futures for Turkey. Energy Policy 38, 4479-4488 (2010)

75. UNESCO: IWRM Implementation in Basins, Sub-basins and Aquifers: State of the Art Review. United Nations Educational, Scientific and Cultural Organization, Paris. http://unesdoc.unesco.org/ images/0018/001817/181790e.pdf

76. Wayne, G.: The beginner's guide to representative concentration pathways, Skeptical Science. https:// gpwayne.wordpress.com/. Accessed 01 Dec 2016

77. Wang, J.J., Jing, Y.Y., Zhang, C.F., Zhao, J.H.: Review on multi-criteria decision aid in sustainable energy decision-making. Renew. Sustain. Energy Rev. 13, 2263-2278 (2009)

78. Wijayatunga, P.D.C., Siriwardena, K., Fernando, W.J.L.S., Shrestha, R.M., Attalage, R.A.: Strategies to overcome barriers for cleaner generation technologies in small developing power systems: Sri Lanka case study. Energy Convers. Manag. 47, 1179-1191 (2006)

79. Van Vuuren, P., Edmonds, J., Kainuma, M., Riahi, K., Thomson, A., Hibbard, K., Hurtt, C., Kram, T., Krey, V., Lamarque, J., Masui, T., Meinshausen, M., Nakicenovic, N., Smith, J., Rose, K.: The representative concentration pathways: an overview. Clim. Change 109, 5-31 (2011). https://doi.org/ $10.1007 / \mathrm{s} 10584-011-0148$ 
Publisher's Note Springer Nature remains neutral with regard to jurisdictional claims in published maps and institutional affiliations.

\title{
Affiliations
}

\section{Clécio Barbosa Souza Júnior ${ }^{1}$. Hagen Koch ${ }^{2}$.} Marianna Siegmund-Schultze ${ }^{1}$. Johann Köppel ${ }^{1}$

\author{
Hagen Koch \\ hagen.koch@pik-potsdam.de \\ Marianna Siegmund-Schultze \\ m.siegmund-schultze@tu-berlin.de \\ Johann Köppel \\ johann.koeppel@tu-berlin.de
}

1 Environmental Assessment and Planning Research Group, Berlin Institute of Technology (TUB), 10623 Berlin, Germany

2 Potsdam Institute for Climate Impact Research (PIK), P.O. Box. 601 203, 14412 Potsdam, Germany 